\title{
THE RELATIONSHIP BETWEEN ENTERPRENURIAL ORIENTATION DIMENSIONS AND PERFORMANCE IN SMALL CANADIAN ICT FIRMS
}

\author{
by \\ Hany Fouda \\ A thesis submitted to the Faculty of Graduate Studies and Research \\ in partial fulfillment of the requirements for the degree of \\ Master of Applied Science in Technology Innovation Management
Department of Systems and Computer Engineering Carleton University \\ Ottawa, Canada, K1S 5B6
}

August, 2007

(C) Copyright 2007 Hany Fouda 


$\begin{array}{ll}\begin{array}{l}\text { Library and } \\ \text { Archives Canada }\end{array} & \begin{array}{l}\text { Bibliothèque et } \\ \text { Archives Canada }\end{array} \\ \begin{array}{l}\text { Published Heritage } \\ \text { Branch }\end{array} & \begin{array}{l}\text { Direction du } \\ \text { Patrimoine de l'édition }\end{array} \\ \begin{array}{l}\text { 395 Wellington Street } \\ \text { Ottawa ON K1A ON4 }\end{array} & \begin{array}{l}\text { 395, rue Wellington } \\ \text { Ottawa ON K1A ON4 } \\ \text { Canada }\end{array}\end{array}$

Your file Votre référence ISBN: 978-0-494-33645-8 Our file Notre référence ISBN: $978-0-494-33645-8$

NOTICE:

The author has granted a nonexclusive license allowing Library and Archives Canada to reproduce, publish, archive, preserve, conserve, communicate to the public by telecommunication or on the Internet, loan, distribute and sell theses worldwide, for commercial or noncommercial purposes, in microform, paper, electronic and/or any other formats.

The author retains copyright ownership and moral rights in this thesis. Neither the thesis nor substantial extracts from it may be printed or otherwise reproduced without the author's permission.
AVIS:

L'auteur a accordé une licence non exclusive permettant à la Bibliothèque et Archives Canada de reproduire, publier, archiver, sauvegarder, conserver, transmettre au public par télécommunication ou par l'Internet, prêter, distribuer et vendre des thèses partout dans le monde, à des fins commerciales ou autres, sur support microforme, papier, électronique et/ou autres formats.

L'auteur conserve la propriété du droit d'auteur et des droits moraux qui protège cette thèse. $\mathrm{Ni}$ la thèse ni des extraits substantiels de celle-ci ne doivent être imprimés ou autrement reproduits sans son autorisation.
In compliance with the Canadian

Privacy Act some supporting forms may have been removed from this thesis.

While these forms may be included in the document page count, their removal does not represent any loss of content from the thesis.
Conformément à la loi canadienne sur la protection de la vie privée, quelques formulaires secondaires ont été enlevés de cette thèse.

Bien que ces formulaires aient inclus dans la pagination, il n'y aura aucun contenu manquant.

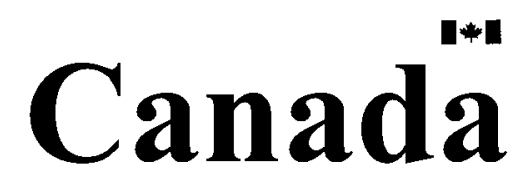




\begin{abstract}
This research examines the individual impact of entrepreneurial orientation dimensions on performance, as measured by revenue growth, in small entrepreneurial organizations operating in the Information and Communications Technologies (ICT) sector in Canada. Entrepreneurial orientation framework includes innovativeness, risk-taking and proactiveness. Innovativeness illustrates entrepreneurial firms' emphasis on research and development. Risk-taking is demonstrated by the firm's behaviour to take on high-risk projects while proactiveness reflects the firm's willingness to initiate actions to which competitors then respond. Six hypotheses were tested using firm-level longitudinal data collected from 63 small ICT firms over a period of four years. The results suggest that entrepreneurial orientation dimensions have a positive impact on small firm's performance. However, the level of impact on the firm's performance varies considerably between the three dimensions. The research also shows that the impact of entrepreneurial orientation dimensions on firm's performance varies depending on its focus on product or services activities.
\end{abstract}




\section{ACKNOWLEDGMENTS}

I am grateful to my thesis supervisor Professor John Callahan for his dedication, stimulating suggestions and continuous guidance in the various stages of preparing this thesis.

I also would like to thank Mr. Richard Dupuy, Chief, Workplace and Employee Survey, Statistics Canada and Mr. Yves Decady, Analyst, Workplace and Employee Survey, Statistics Canada, for their tireless help and support during the development of this research.

Last, but not least, I am thankful to my wife Sally for her relentless support and understanding during the completion of my graduate program. 


\section{TABLE OF CONTENTS}

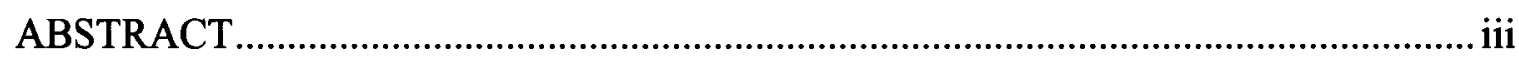

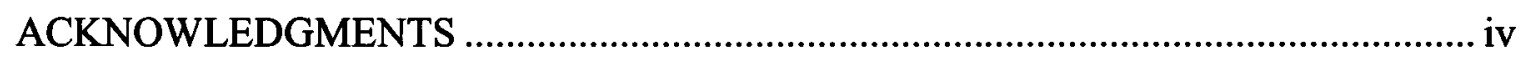

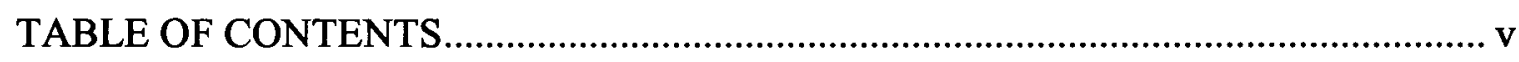

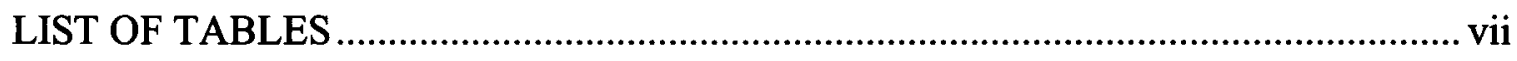

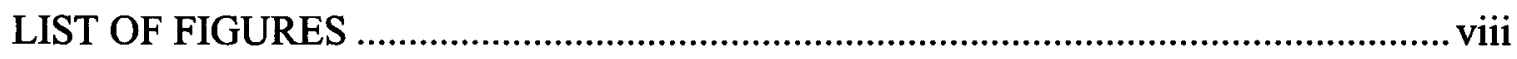

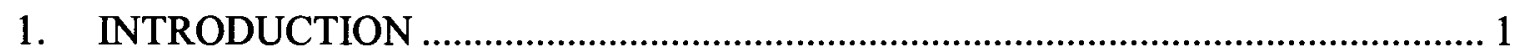

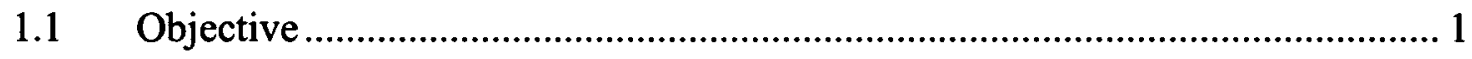

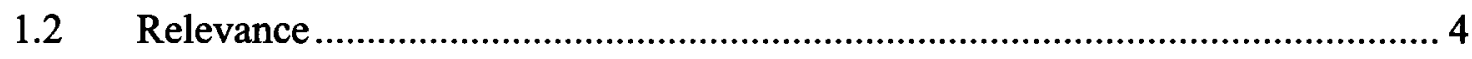

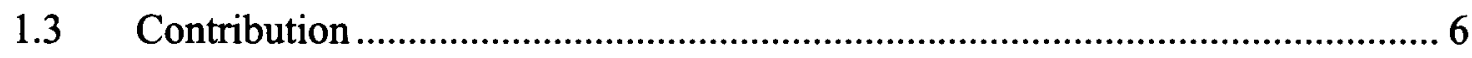

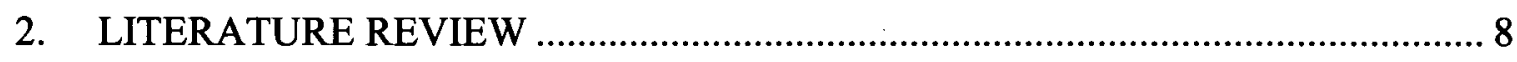

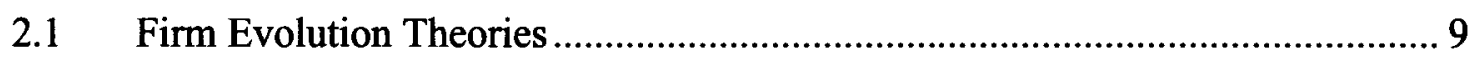

2.2 Factors Affecting Firm's Performance and Growth ....................................... 13

$2.3 \quad$ Literature Insights .............................................................................. 21

3. RESEARCH MODEL AND HYPOTHESIS DEVELOPMENT ……………......... 25

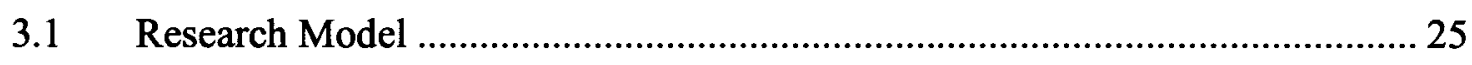

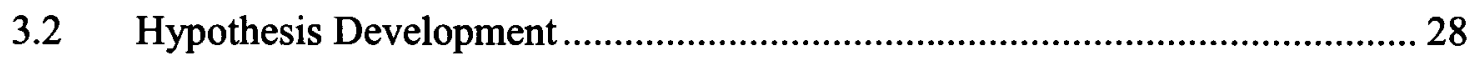

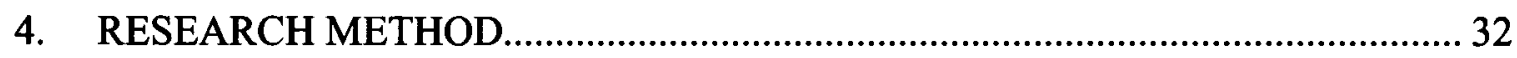

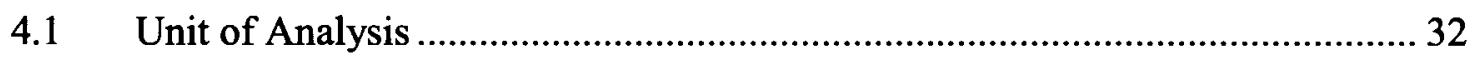

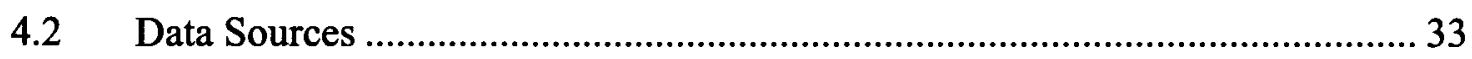

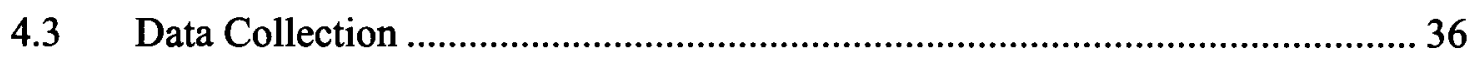

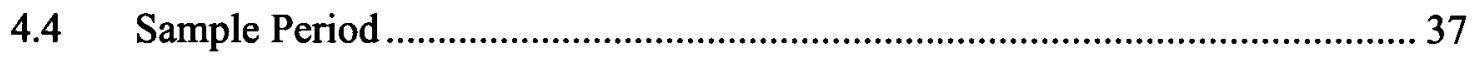




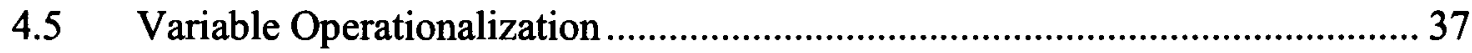

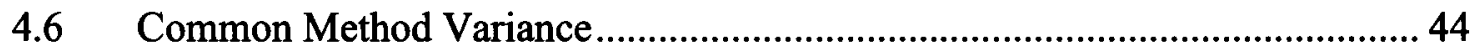

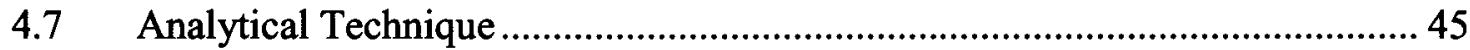

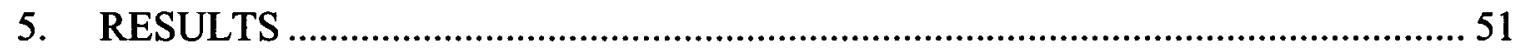

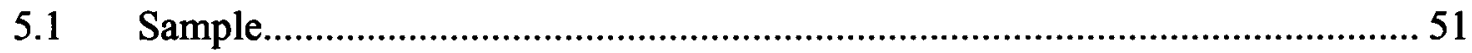

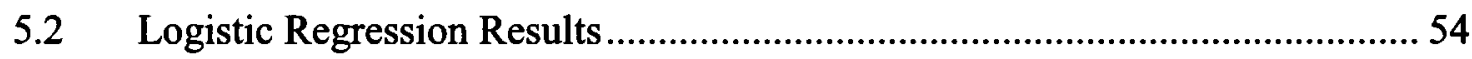

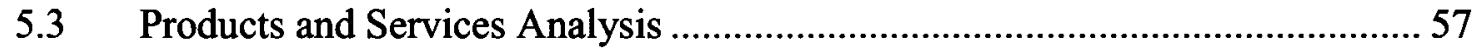

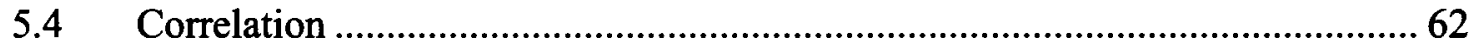

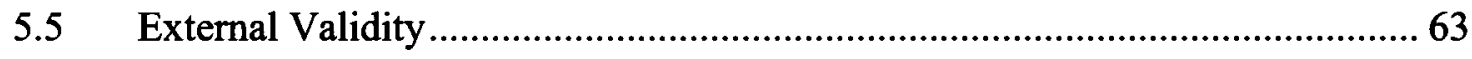

\section{CONCLUSIONS, LIMITATIONS, AND SUGGESTIONS FOR FUTURE}

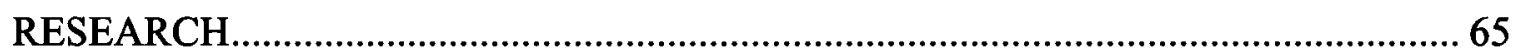

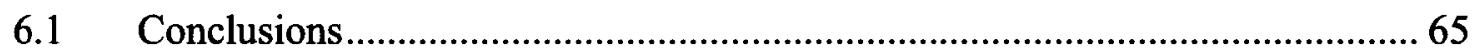

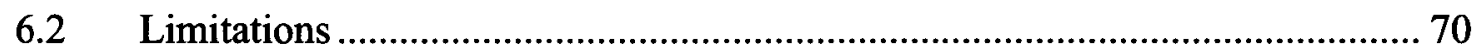

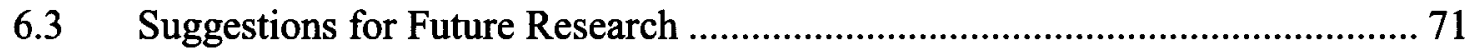

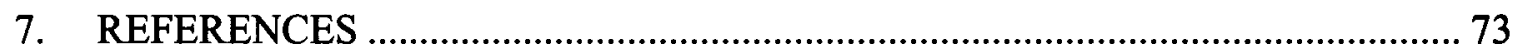




\section{LIST OF TABLES}

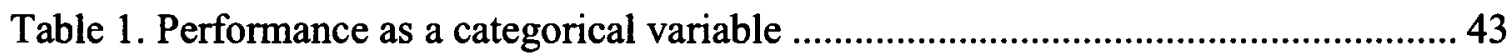

Table 2. Logistic regression analytical results .............................................................. 54

Table 3. Logistic regression analytical results: product category ...................................... 59

Table 4. Logistic regression analytical results: service category...................................... 61

Table 5. Pearson Correlation Results...........................................................................62 


\section{LIST OF FIGURES}

Figure 1. Study's objective and relevance ............................................................. 5

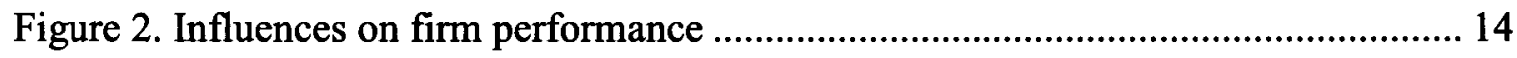

Figure 3. Elements of entrepreneurial orientation and firm's performance..................... 26

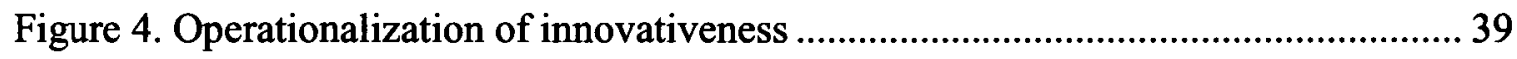

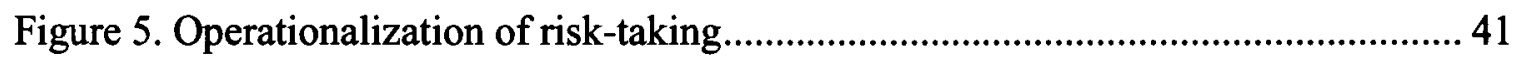

Figure 6. Operationalization of proactiveness ..................................................... 42

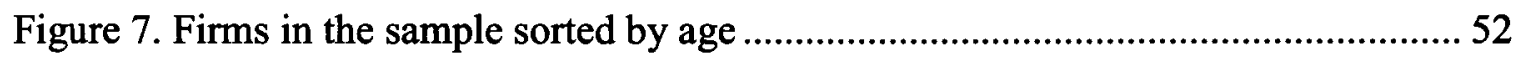

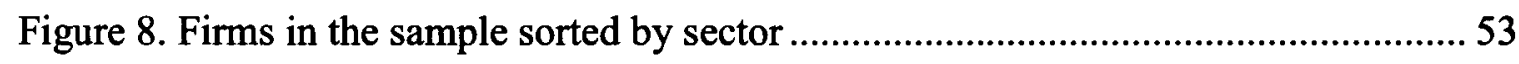

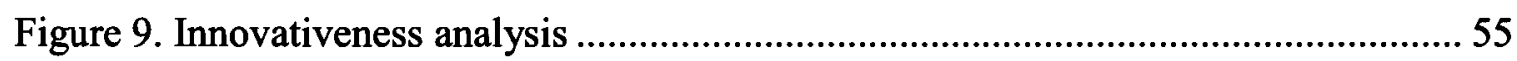

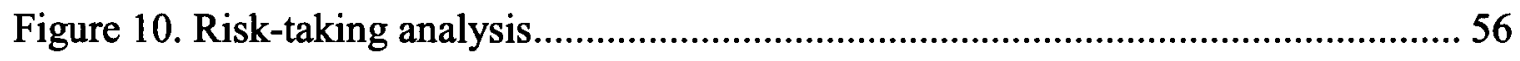

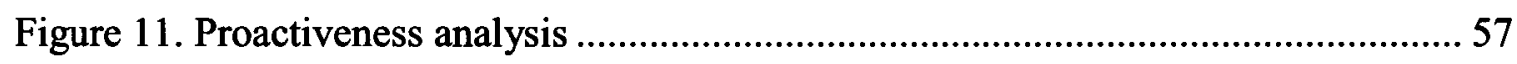

viii 


\section{INTRODUCTION}

This research examines firm-level dimensions that affect performance in small entrepreneurial organizations operating in the Information and Communications Technologies (ICT) sector in Canada. Since most innovations take place in high technology opportunity industries and not in low technology opportunity industries (Audretsch, 1995), ICT is a fertile ground for small firms to survive and grow. High opportunities provide powerful incentives to undertaking innovative activities and provide a ripe economic environment for growth.

\subsection{Objective}

Starting up a new business is one thing, achieving success and sustainable growth is a different matter. Kirchoff's and Phillip's (1989) analysis of small business database in the U.S. suggest that 60 percent of start-ups fail in the first six years and more than 70 percent in the first eight. In Canada, one-half of all new entrants fail prior to their third year and only one in five survive a decade (Baldwin et al., 2000). Since small firms are recognized as a major source of employment and a source of new wealth generation for society (Lee, Lee, and Pennings, 2001), attaining sustainable growth in small firms is more critical to the economy than the mere creation of a large number of start-ups.

The aim of this study is to examine the impact of entrepreneurial orientation dimensions on small firms' performance in the Canadian Information and Communications Technologies (ICT) sector. In dynamic and extremely competitive global economic 
markets, entrepreneurial orientation dimensions could be essential for the firm's ultimate survival and growth (Covin, 1991). According to Industry Canada, ICT branch (Canadian ICT Sector Profile, March 2007), the ICT sector contributed $\$ 65.4$ billion to the Canadian GDP in 2006 and account for $5.9 \%$ of the Canadian output. In 2004, the ICT sector employed 578,400 workers that are characterized by a high level of education ( $38 \%$ of all workers had a university degree compared to a national average of $21 \%$ ).

Using firm-level data for the ICT sector, this research investigates three key entrepreneurial orientation dimensions that have been identified from the review of economic theories and management literature: (i) innovativeness; (ii) risk-taking; (iii) and proactiveness. The operational definition of entrepreneurial orientation used in this research is based on Miller's (1983) conceptualization of this model as a firm's commitment to advance their internal capabilities. Innovativeness reflects a firm's tendency to engage in and support new ideas, novelty, experimentation, and creative processes that may result in new products, services, or technological processes (Lumpkin and Dess, 1996). Risk-taking is illustrated by a firm's willingness to take on high-risk projects with chances of high returns (Covin and Slevin, 1991) and commit large resources in order to seize new opportunities or venture into new and unknown territory (Miller, 1983; Lumpkin and Dess, 1996). Proactiveness reflects a firm's willingness to initiate actions to which competitors then respond and are frequently first-to-market with new product offerings (Covin and Slevin, 1991). 
The research examines the individual influence of these dimensions on small entrepreneurial firm performance as measured by revenue growth, using a firm-level longitudinal database compiled over a period of four years.

There is a level of confusion in literature between entrepreneurship and entrepreneurial orientation adopted by established firms. Entrepreneurship deals with the creation of a new entrant (start-up) where the entrepreneur identifies the opportunity, controls the resources, takes the risk and reaps the benefits. Entrepreneurial orientation deals with process where the organization as a whole takes the risk, owns the concept, recovers from failures and the rewards are limited based on the internal compensation structure. 


\subsection{Relevance}

According to recent data from Statistics Canada's Business Register of June 2005, ninety eight percent of businesses in Canada have fewer than 100 employees and are categorized as "small". Small firms make up ninety seven percent of goods-producing businesses and ninety eight percent of all service-producing business in Canada. These staggering numbers highlight the importance of small firms to the Canadian economy. Many other developed economies exhibit a similar proportion of small businesses. Despite the social and economical significance of small business sector, small firms continue to fail at a relatively high rate, thereby creating pressure on the economy. Figure 1 illustrates the importance of small firm's performance to the firm and the economy as a whole and highlights the objective of this research.

Growth is a fundamental objective for the firm. It affects the firm's survival, profitability and competitiveness. Large firms relentlessly pursue growth strategies in order to maximize shareholders value and increase financial rewards. The stakes are even higher for a small entrepreneurial business where founders, employees, customers and creditors have vested interest in attaining long-term continuity of the firm. New firms are normally confronted by serious constraints such as lack of capital, resources, long standing relationships, reputation, experiences and customers. Bhidé (2000) argues that new entrepreneurial firms can overcome many of these constraints by focusing on niche opportunities with "high uncertainty". In particular, niche opportunities driven by market turbulence because of new technology, regulatory regime, fashion, or other external factor, are ideal for new firms (Bhidé, 2000). Unsettling markets provide new firms with 
attractive features such as limited price competition, few competitive forces, tolerant and inexperience customers and low switching costs.

However, as studies have shown, very few small firms are capable of evolving into mature businesses and have the willingness, knowledge and capacity to pursue a strategic rather than opportunistic approach in order to achieve growth. Bhidé (2000) asserts that new firms must make larger, longer term investments than those required during the early years of the venture to achieve maturity.

\section{Small Firm's Performance} is important

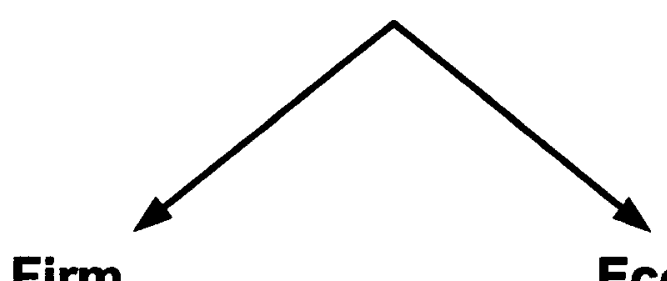

Firm

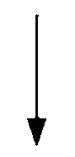

- For its long term survival and evolution

- For its stakeholders (founders, employees, customers and creditors)

- For the community

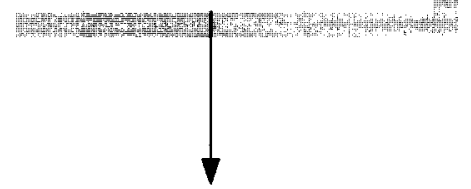

Economy

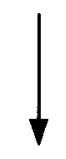

- For its contribution to the GDP and exports

- For employment

- For skills generation

- For corporate taxes

- For quality of life

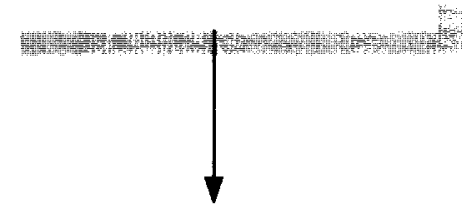

The purpose of this research is to examine firm-level dimensions that affect small firm's performance

Figure 1. Study's objective and relevance 
This research attempts to highlight some of the key factors to which entrepreneurs and managers at small ICT firms must pay attention while attempting to transform their firms from start-up to fully developed enterprises. The same set of entrepreneurial skills and traits that helped the firm during start-up stage may not have the same impact during the transitional stage (Bhidé, 2000).

In addition, the research provides insights to governments and institutions eager to shift their focus from programs geared to conceiving more start-ups to policies and strategies directed towards helping existing and relatively new small firms grow and achieve longevity.

\subsection{Contribution}

This research makes three contributions to the literature. First, it aims to improve the understanding of the impact of entrepreneurial orientation dimensions on performance and evolution of small firms. Unlike past studies (Miller, 1983; Covin and Slevin, 1991; Zahra, 1991, Zahra and Covin, 1995; Wiklund, 1999) that examined the broader concept of entrepreneurial orientation on firm's performance, this research attempts to analyze the impact of each dimension independently on performance. This may result in a better understanding of the impact of each dimension as an element in the generic profile of firm's level of entrepreneurial orientation.

Second, this research relies on firm-level longitudinal data gathered over a four-year period. Other than Zahra and Covin (1995) and Wiklund (1999), existing studies in 
entrepreneurial orientation relied on data sampled over a much shorter period of time, normally within the same year in which the study was conducted. Entrepreneurial activities, such as the introduction of new innovative products or penetrating new markets, require a much longer time span to have an impact on firm's performance. The longitudinal analysis of this research is novel among the studies focusing on entrepreneurial orientation.

A third contribution of this study is its reliance on data sampled from a single industry: Information and Communications Technologies (ICT). Prior studies have relied on data from multiple industries with few researchers controlling for industry effects. Eliminating inter-industry variation permits the examination of the impact of entrepreneurial orientation dimensions on firm's performance under controlled environmental conditions characterized by high-growth opportunities that allow small firms to survive. Other industries that share characteristics similar to the ICT sector should also benefit from this research. 


\section{LITERATURE REVIEW}

A large part of the economic environment in any country is dependent on the performance of firms. Growth rates, unemployment, productivity and standard of living are highly correlated with the economic performance of firms. In general terms, firm performance is determined by the success of selling products and services in the market and by the efficient transformation of labour and capital to sellable products and services. Hence, firms' success and growth have a significant impact on the economy.

The determination of growth and profitability in large firms is a well researched area (Sawyer, 1985). Small firms success have been popular research topic since Birch (1979) concluded that small firms create more new jobs for the economy than large firms. In the last quarter of the 20 th century and the beginning of the 21 st century, the importance of small firms increased significantly as a key source of employment (Acs and Audretsch, 1990). In a study based on 1989-1993 firm data, Hart and Oulton (1996) found that smaller firms generated proportionately more jobs than larger ones. Small firms have played a major role creating new jobs and providing a safety net of employment during market turbulences (Davidsson et al., 1999).

Some studies have been devoted to the identification of success factors of small firms in various industries (Storey, 1994; Eisenhardt et al., 1990; Audretsch et al., 2001). However, careful examination of these studies indicates that determinants of success of small firms are less straightforward than one might expect. Many factors have been identified but different researchers frequently reach different conclusions depending on 
where the study took place, which industry or sector was examined, and what scale of activities and data gathering have been included in the research.

This chapter is organized into three sections. The first section examines existing theories that might help explain why some small firms undergo the transformation into mature business while many fail. The second section reviews literature exploring the determinants of success and growth in small firms. The third section provides lessons learned from the literature review.

\subsection{Firm Evolution Theories}

Small firms normally face numerous challenges during their attempt to grow including:

- Restricted access to capital that would allow them to undertake new initiatives such as expanding production, building a brand identity and developing sales channels (Ferrier, 2001).

- Lack of a formal organization structure to organize firm assets and capabilities and cope with external constraints. Without changes in organizational structure, the technological, financial and personnel economies of growth and size could not be realized (Chandler, 1962).

- Limited capacity for growth. Penrose $(1959 ; 1995)$ argues that a firm's ability to grow is directly related to its ability to add managerial capacity to accommodate its growth. To build such capacity, a firm must develop internal policies such as incentives and control systems, recruiting and training practices and foster relationships and alliances. 
Most firms undergo a gradual growth process. Life cycle models explain the growth stages of firms. Churchill and Lewis (1983) defined five development stages: existence, survival, success, take off and maturity. Using exploratory cluster analysis of crosssectional data supplied via mailed questionnaires by 133 manufacturing SMEs from 'high technology' industries in the United States, Hanks et al. (1993) derive a life-cycle model with four development stages and two disengagement (or arrested development) stages:

- Start-up - young, small firms with simple organizational structures. The organization is highly centralized and quite informal. There is little functional specialization with product development the focal priority.

- Expansion - slightly older and larger firms with more complex organizational structures. The organization is still very centralized and a little more formal than in the start-up stage. Functional specialization is generally adopted. Product commercialization continues to be the focal priority.

- Maturity - although not necessarily older, on average, than in the expansion stage, firms in this stage are typically more than twice as large. Organizational structures are more complex than earlier stages. Centralization is declining and formalization increasing.

- Diversification - firms are generally medium-sized with increasing tendency to have departmental structures.

Hanks et al. (1993) further describe two apparently stable and sustainable disengagement configurations or stages in their taxonomic life-cycle model as follows: 
- Life-style - these firms are slightly larger than those in the start-up stage, but are generally much older. They are still organized and managed like start-up businesses. These firms appear to have disengaged from the growth process after establishing their viability at relatively small sizes following start-up. Researchers found that for many small business managers, the negative effects of growth appeared to outweigh the positive outcomes once the firm had reached the size of five to nine employees.

- Capped growth - these enterprises are slightly larger than those in the expansion stage, but are generally much older. Organizationally, they are somewhat less complex than typical businesses in the expansion stage. These firms appear to have disengaged from the growth process after successfully expanding to modest sizes following creation as long as external factors do not destroy their market niche or ineffective management reduces their competitive abilities.

The life-cycle literature suggests that organizations evolve in a consistent and predictable manner (Hanks et al., 1993). Scholars have argued that as a firm moves through various stages of growth, it faces a different set of problems and challenges, resulting in the need for different management skills, priorities, and structural configurations.

Business strategy models, on the other hand, emphasize the role of top managers in formulating and implementing strategies that could make significant contribution to their firm's growth and longevity. A strategy is a pattern identified in a series of decisions or 
actions. An intended strategy is planned by decision makers whereas an emergent or realized strategy is a product of any planned and unplanned actions. Andrews (1980) states that a corporate strategy is a broad term encompassing the pattern of company purposes and goals, and the major policies and actions for achieving them. Together they define the business or businesses the company is to be involved with and the kind of company it is to become. Formulating a strategy requires the consideration of factors such as firm's resources and competencies, market opportunities and threats (Bhidé, 2000). An optimal strategy is the one where firm's goals, capabilities and resources are aligned with current and future market opportunities. Implementing a strategy involves establishing and rejuvenating the organizational structures, incentives schemes, and the recruitment of the right people to perform the tasks.

Porter (1980) has identified three generic business strategies that may lead to competitive success. His first generic strategy is pursuit of overall cost leadership for the entire product/service market. Various actions such as increasing production efficiencies, under pricing competitors, and cutting costs are directly related to the successful pursuit of this strategy. Porter's second strategy is differentiation of products so that the customers see them as unique or very distinctive. Distinctive brands, a heavy investment in product innovation, and memorable marketing campaigns are linked directly to this general strategy. The third strategy involves focusing on only a narrow segment of a larger market, emphasizing either overall cost leadership or differentiation to achieve the goals that top managers set for the organization. Porter's (1980) model of competitive strategy 
proposed that a firm's position within an industry was an important factor in attaining competitive advantage.

The resource-based view (RBV) of the firm argues that firms possess resources or assets, some of which enable them to achieve competitive advantage, and a subset of those that lead to superior long-term performance. Penrose (1959) proposed a model that treated the firm as an "administrative unit" that was not tied to a particular market or technology. The "unit", with the availability of the proper resources, could "produce anything of which a demand can be found or created". Resources that are valuable and rare can lead to the creation of a competitive advantage. That advantage can be sustained over longer time periods to the extent that the firm is able to protect against resource imitation, transfer, or substitution. Recent work in the resource-based view has shifted focus to the firm's internal capabilities - for example, organizational knowledge, culture, compensation and incentives - as important sources of the competitive advantage (Henderson, 1994).

\subsection{Factors Affecting Firm's Performance and Growth}

Research activities in determining the factors influencing the performance of firms have mainly focused on three streams: entrepreneur-related factors, industry-related factors and firm-related factors. Figure 2 illustrates the three research streams and lists the key elements associated with each stream. 


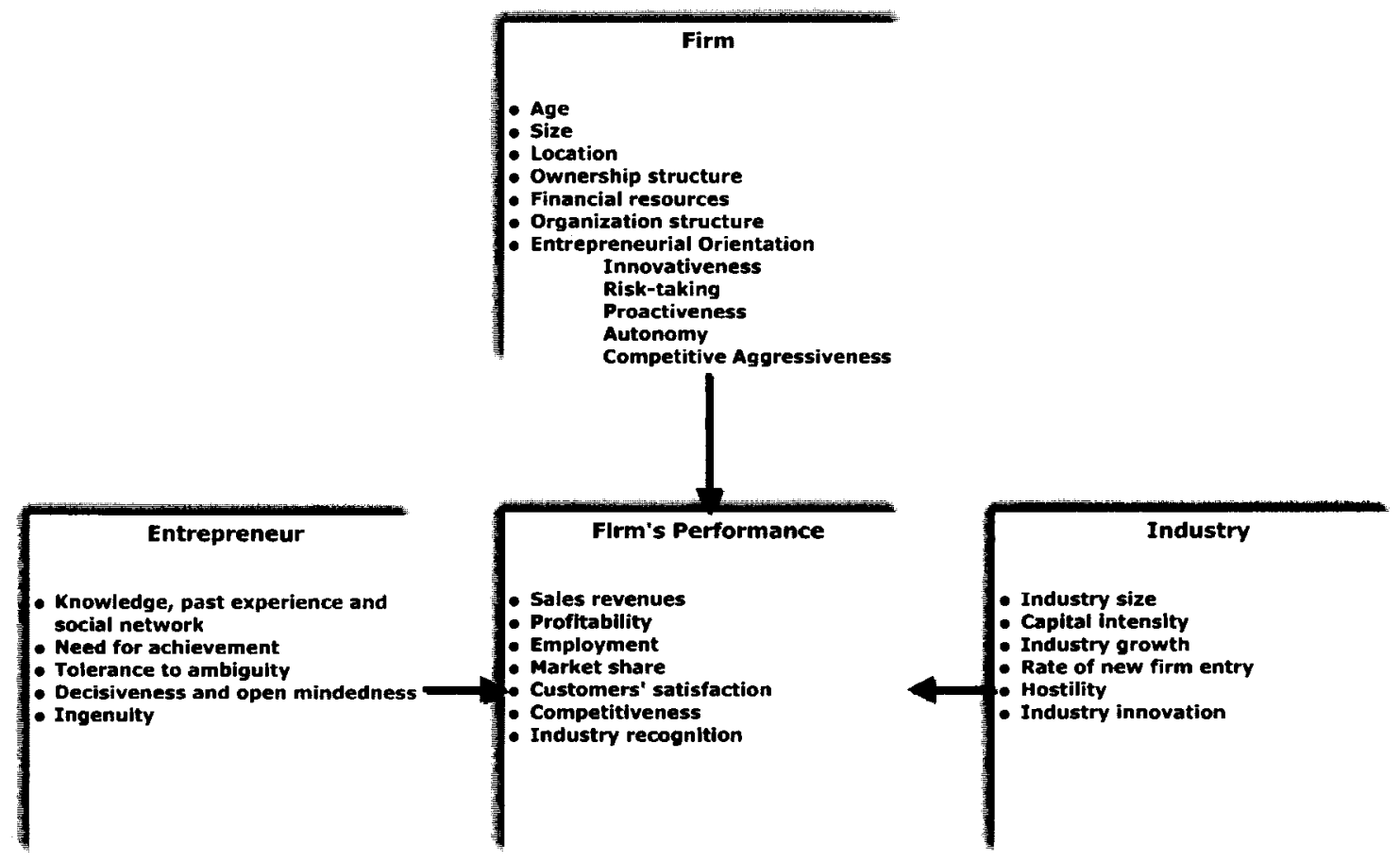

Figure 2. Influences on firm performance

\subsubsection{Entrepreneur-related factors}

In small firms, ownership and control are typically in the hands of few decisions makers, normally referred to as "founders", who are able to exert powerful influence on the way the firms perform and grow. Cooper $(1971,1982)$ and Cooper et al. (1995) showed that the strengths and weaknesses of the founders are themselves the strengths and weakness of the firms. Drucker (1985) distinguished between administration and entrepreneurship by arguing that the latter entails innovation that involves change, creativity and discovery. Drucker (1985) went on to define innovation as a means by which 
entrepreneurs may exploit change in order to create new service and business opportunities. Thus, willingness to innovate is the most prominent attribute of being an entrepreneur. Stuart et al. (1990) concluded that the relevant experience of the founders is an important prediction of success. Small firms start by imitating or modifying ideas the founders encountered in their past experience or previous jobs that give them firsthand indication of the viability of the opportunity and a good knowledge of the market. Shane (2000) argues that entrepreneurs discover opportunities related to the information they already possess as a result of their past experience in certain sectors and markets.

Many studies in this stream attempted to identify the 'entrepreneurial personality' using complex psychological models such as McClelland (1961). Such studies typically use survey questionnaires to assess whether certain attributes have a high occurrence among entrepreneurs. Hornaday (1982) lists some of the attributes including need for achievement; willingness to take risks; internal control mechanisms such as selfconfidence and resilience; tolerance of ambiguity; and type A personality. Some researchers have contested these results, and labelled the drive to form a distinctive profile for entrepreneurs as "fruitless" (Kelley and Rice, 2002). Other studies focused on level of education, age of the founders and motivation factors. Wicker et al. (1989) found no convincing evidence, however, that demographic characteristics play an important role in explaining the failure of firms. They were unable to establish a clear connection between motivation factors and success. 


\subsubsection{Industry-related factors}

Small firms that enter an industry are confronted with a size disadvantage, lack of economies of scale, and limited tangible and intangible assets. Entrepreneurs who are normally constrained by capital cannot contemplate high volume production, where substantial investment in assets is required in advance for revenue generation. For example, they cannot start a car assembly operation, develop a major drug or build a gas pipeline. Instead, most small firms start in niche markets where up-front investment in development, production and marketing are within their limited capabilities. Empirical studies have shown that although short-term post entry survival is lower, long term survival rates are systematically higher in industries with high technology opportunity conditions for small firms (Audretsch, 1995). Small firms are more likely to survive in industries characterized by an entrepreneurial regime, where entrants to the market have advantages with technological innovation over the incumbents (Audretsch, 1991; Audretsch and Mahmood, 1995). Siegfried et al. (1994) identified other factors that are considered incentives or impediments to growth of small firms such as market growth, capital cost, economies of scale as well as behaviour of incumbent firms with respect to excess capacity and pricing strategy.

\subsubsection{Firm-related factors}

Firm-related factors are more focused on the characteristics of the firm and its economic activities. Cooper (1982) and Storey (1985) found a positive relationship between the size, represented in total number of employees, and success of the new firm. Evans 
(1987a) was able to use the U.S Small Business Database to identify the existence of a strong positive relationship between the likelihood of survival and the firm size in 81 of the 100 4-digit Standard Industrial Classification (SIC) of industries examined. By sorting the firms into intervals related to their age, Evans (1987a, 1987b) showed that firm age is an important factor in relation to firm growth. Firm growth seems to decrease with age. In other words, maturity adds to the stability of the firm growth rate. Storey (1985) took a financial approach and pointed out the importance of a healthy financial basis for the success of small firms. Krugman (1991) presented the strong relation between firm location, where the firm gain the best access to the highest demand for its goods, and growth. Furthermore, clustering, or the ability of a firm to be located in a region which already has a large production of similar products, has proven to influence firm growth due to proximity to complementary suppliers, potential customers and access to a qualified and specialized workforce (Krugman, 1998). Other factors that have been investigated include the ownership structure and the availability of an advisory board to the small firm.

Organizational structure of small firms and the link between these structures and the performance of the respective firms have also been studied. Organizational structure models focus on the distribution of task and activities, decision-making process, and coordination between individuals and department for day-to-day activities. Hart et al. (1999) found that hierarchical, centralized structures with strongly specialized employees perform well in terms of growth. Although the relationship between organizational 
structure and small firm performance is relevant, small firms are unique in their design, focus and size - which make it harder for researchers to recommend a specific structure.

The resource-based view (RBV) emphasizes firm idiosyncratic resources (e.g., Barney, 1991; Penrose, 1959), especially resources that reside within organizations. The resource-based approach can be viewed as a continuing search for competitive advantage by the creation, acquisition and utilization of unique firm resources (Barney, 1991). The resource-based view regards the firm as a bundle of resources and suggests that their attributes significantly affect the firm's competitive advantage and by implication its performance (Barney, 1991; Penrose, 1959). Most conspicuous among these resources are those that are valuable, scarce, imperfectly tradable, and hard to imitate (Barney, 1986). The most prominently investigated factors include human, technological, financial resources, organizational culture, and managerial capabilities (Barney, 1986).

Inspired by the resource-based view, the term "entrepreneurial orientation" captures the organizational process, methods and culture used to run a business (Miller, 1983; Lumpkin and Dess, 1996). Entrepreneurial orientation should be differentiated from entrepreneurship that deals with creating new business and is focused on identifying niche opportunities the business will initially pursue. Entrepreneurial orientation is a process to formulate and implement those "methods, practices and decision making styles managers use" to run the firm (Lumpkin and Dess, 1996). Miller (1983) used the dimensions of "innovativeness", "risk-taking" and "proactiveness" to characterize firms that exhibits entrepreneurial orientation. According to Miller (1983): 
"In general, theorists would not call a firm entrepreneurial if it changed its technology or product-line (innovated according to our terminology) simply by directly imitating competitors while refusing to take any risks. Some proactiveness would be essential as well. By the same token, risk-taking firms that are highly leveraged financially are not necessarily entrepreneurial. They must also engage in product-market or technological innovation."

Innovativeness reflects a firm's willingness to introduce novelty through experimentation and use of creative processes aimed at developing new products and services as well as new processes. Risk-taking refers to the ability of the firm to make decisions and take actions without certain knowledge of the outcome. Proactiveness is a forward-looking perspective characteristic of a market leader that has the foresight to seize opportunities in anticipation of future demands.

Covin and Slevin (1991) also proposed the use of innovativeness, risk-taking and proactiveness as the key dimensions of entrepreneurial orientation. However, they refer to these as "entrepreneurial postures" and argued that these dimensions can be applied to both "corporate" and "independent" entrepreneurs. Covin and Slevin adopted Miller's (1983) dimensions and described them as follows:

“An entrepreneurial strategic posture is characterized by frequent and extensive technological and product innovation, an aggressive competitive orientation, and a strong risk-taking propensity by top management" 
They believed that firms with such "entrepreneurial postures" are willing to take on high risk projects with chances of very high returns and are bold and aggressive in pursuing opportunities.

Lumpkin and Dess (1996) extended the entrepreneurial orientation framework to include two other dimensions. They built on Miller (1983) and Covin and Slevin (1991) to include "autonomy" and "competitive aggressiveness". Autonomy was defined as “independent action by an individual or team aimed at bringing forth a business concept or vision and carrying through to completion". On the firm level, this implies an empowerment to act and make decisions without restricting processes or rules. Lumpkin and Dess (1996) defined competitive aggressiveness as "an intense effort to outperform industry rivals." A firm that demonstrate competitive aggressive behaviour has "combative posture or an aggressive response aimed at improving position or overcoming a threat in a competitive marketplace". Covin and Slevin $(1989 ; 1991)$ suggested that proactive firms compete aggressively with other firms, thus addressing competitive aggressiveness by equating it with proactiveness.

The growing interest in entrepreneurial orientation arises from its potential impact on a firm's performance and its ability to compete in the marketplace. Theoretical links between entrepreneurial orientation and firm performance are readily available in the academic literature (Lee, Lee, and Pennings, 2001; Wiklund, 1999; Zahra and Covin, 1995). A large number of studies suggest that firms who pioneer the development and introduction of new products or technologies are often rewarded with better performance 
than non-innovative firms (Lengnick and Hall, 1992; Tushman and Anderson, 1986). These proactive, risk-taking firms would fit the framework of entrepreneurial orientation. However, many high performing firms aggressively pursue cost leadership strategies while de-emphasising innovation and risk-taking (Dess, Lumpkin and McGee, 1996). Furthermore, as noted by Nelson and Winter (1982), research has indicated that firms may enjoy a greater long-term benefit from imitation strategies than from high levels of innovativeness. The relationship between entrepreneurial orientation and firm performance is still an important question. Despite the theoretical link, empirical evidence linking firm's performance to its entrepreneurial orientation behaviour is still scarce.

\subsection{Literature Insights}

A number of points can be drawn from the literature review:

\subsubsection{Strategy vs capabilities}

Many of the current business strategy models, such as Porter's five forces framework (Porter, 1980), deal almost exclusively with "economic" elements (barriers of entry, direct competitors, competitive advantages, customers and suppliers powers). These models do not include organizational capabilities in their framework and are more oriented towards mature firms that have the capacity to evaluate economic elements in a systematic way. The resource based view offers a much broader framework. It regards the firm as a distinctive bundle of tangible assets (such as plants, physical assets) and intangible assets (brand, customer relationship, products, innovative technologies, 
distribution networks, people, past experiences and internal capabilities). To achieve growth and longevity, a small firm needs to invest in a broad base of assets, leverage its internal capabilities and develop mechanisms to coordinate the deployment of assets and capabilities.

\subsubsection{Industry environment and small firms}

Industry sectors that are characterized by high level of technological opportunities, like the ICT sector, are fertile grounds for small firms to survive and grow. Acs and Audretsch (1990) relate concentrated market structures to high levels of technological

opportunity and entry. High opportunities provide powerful incentives to undertaking innovative activities and provide an economic environment for growth. Miller and Friesen (1982) argue that:

"Entrepreneurial firms are often found in dynamic and hostile environments because their venturesome managers prefer rapidly growing and opportuneful setting; settings which may have high risks as well as high rewards. Such firms may even be partly responsible for making the environment dynamic by contributing challenging product innovations. Because innovation prompts imitation, the more innovative the firms, the more dynamic and competitive (hostile) their environment can be".

Miller (1990) asserts that entrepreneurial-type strategies are likely to be more successful when addressing customers in dynamic environments. Dynamic environments are 
associated with high unpredictability of customers and competitors and high rates of change in market trends and industry innovation (Dess and Beard, 1984). Opportunities become abundant in such dynamic environments allowing small firms with entrepreneurial orientation to innovate and pursue new markets a chance to grow. Zahra (1993b) found that there was a strong positive relationship between entrepreneurial orientation and firm performance in dynamic growth environments, whereas this relationship was largely negative among firms operating in static and mature environments.

\subsubsection{The multi-dimensional aspect of entrepreneurial orientation}

Lumpkin and Dess (1996) believe that it is essential to recognize the multi-dimensional nature of the entrepreneurial orientation framework. They suggested that additional research should explore the independence of entrepreneurial orientation dimensions and their contingent relationships to performance (Lumpkin and Dess, 1996). Dess, Lumpkin and McGee (1999) argue that "an appreciation of the multidimensionality and independence of the sub-dimensions of an entrepreneurial orientation can enhance normative and descriptive theory building". Other scholars have suggested that all the dimensions are present simultaneously in an entrepreneurial firm (e.g., Miller, 1983, Covin and Slevin, 1989). Covin and Slevin theorized that the three dimensions of entrepreneurial orientation acted together to "comprise a basic, unidimensional strategic orientation" (Kreiser et al., 2002). Although it is possible that a firm would exhibit all 
dimensions at the same time, their relationships with firm's performance may vary in strength or change over time.

\subsubsection{Entrepreneurial orientation and firm performance}

As recognized by Zahra (1991) and Covin and Slevin (1991), there is little solid empirical evidence of the link between entrepreneurial orientation and firm performance. Hart (1992) argues that entrepreneurial-type strategies may even be associated with poor performance under certain conditions. One possible explanation is that the bulk of studies in the area use cross sectional designs. In order to empirically test whether entrepreneurial orientation actually leads to better performance, longitudinal data are necessary where the dimensions are measured at one point in time and performance outcomes are measured later. Recently, studies based on longitudinal data (Zahra and Covin, 1995; Wiklund, 1999) found that those businesses that adopt entrepreneurial orientation dimensions perform better. Still, these studies used aggregate measures of entrepreneurial orientation rather than investigating the differential impact of each dimension on firm's performance. 


\section{RESEARCH MODEL AND HYPOTHESIS DEVELOPMENT}

This chapter is organized into two sections. The first section explains the research model used in the study. The second section provides the hypotheses anchored around the research model.

\subsection{Research Model}

The objective of this research is to examine the impact of entrepreneurial orientation dimensions in ICT small firms on their performance. High-tech industries are dynamic and hostile environments where organizations often respond to challenging environmental conditions by taking-risks, innovating, and exhibiting proactive behaviours, thus adopting an entrepreneurial orientation strategy (Khandwalla, 1987, Covin and Slevin, 1991).

Miller (1983) has argued that "an entrepreneurial firm is one that engages in productmarket innovation, undertakes somewhat risky ventures, and is first to come up with proactive innovations, beating competitors to the punch. A nonentrepreneurial firm is one that innovates very little, is highly risk averse, and imitates the moves of competitors instead of leading the way".

This study adopts the entrepreneurial orientation framework as suggested by Miller (1983) and Covin and Slevin (1991), and investigates the extent to which each of the three dimensions of entrepreneurial orientation, innovativeness, risk-taking and 
proactiveness affect small firm performance in the ICT sector. Figure 3 illustrates the research model.
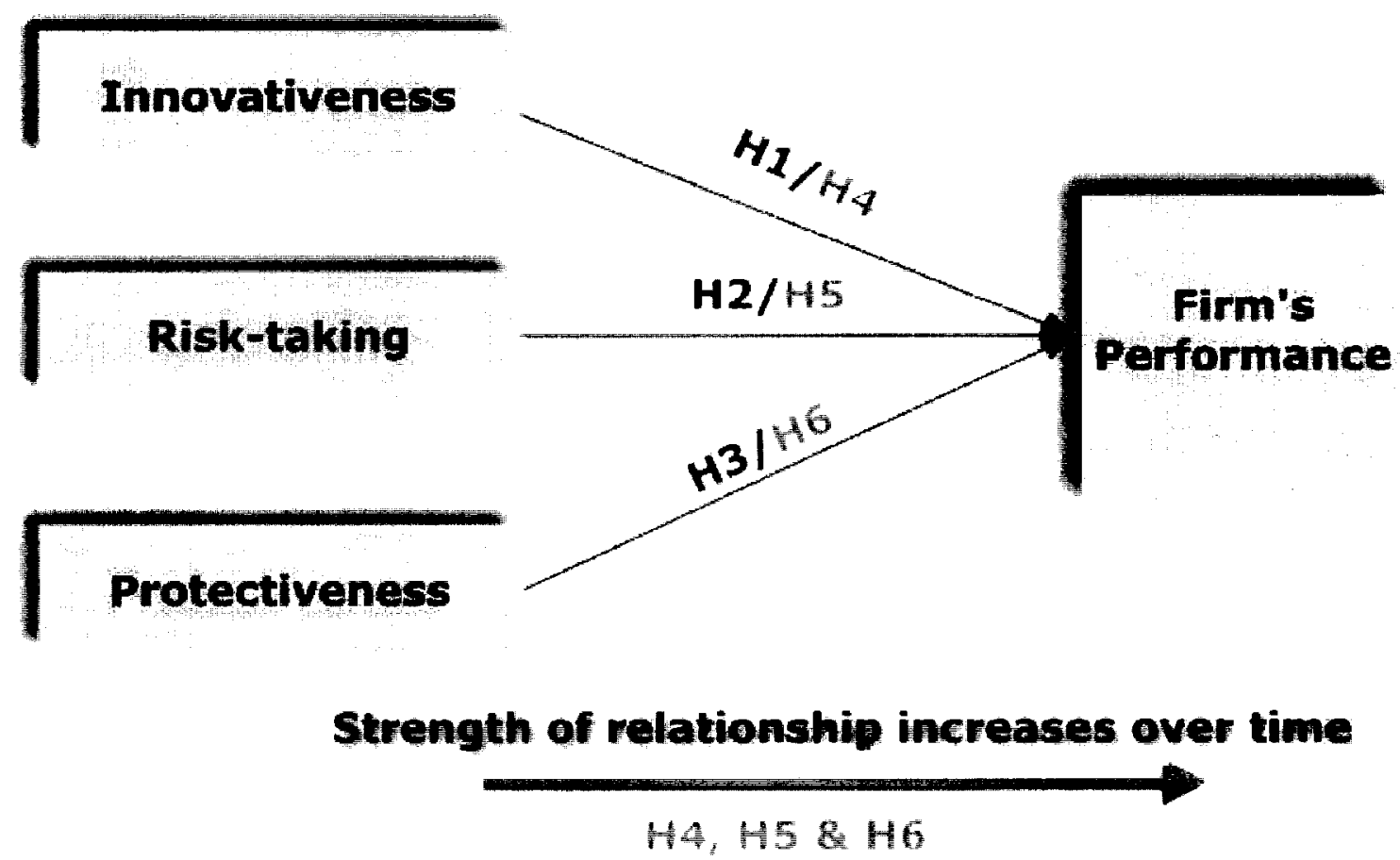

Figure 3. Elements of entrepreneurial orientation and firm's performance

Innovativeness illustrates entrepreneurial firms' emphasis on technological leadership and research and development (Covin and Slevin, 1991). According to Lumpkin and Dess (1996), innovativeness “reflects a firm's tendency to engage in and support new ideas, novelty, experimentation, and creative processes that may result in new products, services, or technological processes". 
Innovativeness includes fostering a spirit of creativity, supporting RandD and experimentation, developing new processes, introducing new products/services, and technological leadership (Lumpkin and Dess, 2001). Innovative entrepreneurial organizations often are first-to-market with new product offerings (Khandwalla, 1977). Innovativeness can span a continuum from a willingness to make a marginal improvement to a major commitment to be a technological leader (Lumpkin and Dess, 1996). Further, innovativeness and performance have been shown to exhibit a positive linear relationship (Shane, 1993; Deed et al., 1998). ICT firms rely on technology as a key strategic resource that can be used to develop a competitive advantage through innovation (Kelley and Rice, 2002).

Risk-taking behaviour is illustrated by a firm's willingness to take on high-risk projects with chances of high returns (Covin and Slevin, 1991) and commit large resources in order to seize new opportunities or venture into new and unknown territory (Miller, 1983; Lumpkin and Dess, 1996). Overcoming growth constraints also involves risk as small firms try to expand their niche markets and compete with larger organizations in mainstream markets. Begley and Boyd (1987) have shown that risk-taking has a positive effect on firm performance up to a point beyond which increases in risk-taking begin to exert a negative effect on performance.

Proactiveness reflects the entrepreneurial organization willingness to initiate actions to which competitors then respond, and are frequently first-to-market with new product offerings (Covin and Slevin, 1991). Proactiveness is the opportunity-seeking, forward- 
looking perspective that involves introducing new products/services and acting in anticipation of future demand. Lumpkin and Dess (2001) describe proactiveness as a response to opportunities and competitive aggressiveness as responsive to threats.

Proactiveness involves a wide variety of activities including identifying opportunities and market trends, assessing strengths and weaknesses of opportunities, and forming teams capable of exploiting them. It entails a forward-looking prospective that is accompanied by innovative or new-venturing activity. Lumpkin and Dess (2001) found that proactiveness was more important to firms in the early stages of industry development than in more mature industries. This is of particular interest to entrepreneurial technology firms that are often operating in early stages of an industry.

\subsection{Hypothesis Development}

Covin and Slevin (1988) argued that entrepreneurial orientation could be best measured by summing together "the extent to which top managers are inclined to take businessrelated risks, to favour change and innovation in order to obtain competitive advantage for the firm, and to compete aggressively with other firms". Many researchers have measured entrepreneurial orientation as the compound total of innovativeness, proactiveness and risk-taking dimensions (e.g. Miller and Friesen, 1983; Covin and Slevin, 1989; Covin and Slevin, 1991; Zahra, 1991; Zahra and Covin, 1995; Wilklund, 1999). Zahra and Covin (1995) and Wilklund (1999) concluded that there is a positive relationship between entrepreneurial orientation as a construct and firm performance. Other scholars suggest that each of entrepreneurial orientation dimensions make a unique 
contribution to the entrepreneurial nature of the firm (Lumpkin and Dess, 1996). Further, Lumpkin and Dess (2001) suggest that each dimension of the entrepreneurial orientation construct may have a differential relationship with key outcome variables such as firm

performance. Kreiser et al. (2002) suggest that researchers should measure innovativeness, proactiveness and risk-taking as unique variables when a differential relationship is posited to exist

\subsubsection{Innovativeness}

Innovativeness indicates firm's willingness to engage in new idea generation, experimentation and RandD activities resulting in new products/services (Lumpkin and Dess, 1996). Without innovation, small entrepreneurial firms would have to compete with incumbent firms with "me too" products and services. Direct competition with established incumbents has a high probability of failure due to the limited resources available to small firms. Based on past research, an entrepreneurial firm that exhibits a level of innovativeness gains a considerable competitive advantage that leads to growth and improved financial results. This leads us to the first hypothesis:

Hypothesis 1: The level of a small technology firm's innovativeness is positively associated with the firm's performance. 


\subsubsection{Risk-taking}

Small entrepreneurial firms typically display risk-taking behaviour, demonstrated in large resource commitments to seize new opportunities in the marketplace (Miller, 1983). In other words, aggressive firms risk the expenditure of resources to control additional resources. Small firms aspiring for higher performance must step-out of their comfort zones and compete with larger organizations in mainstream markets. Thus:

Hypothesis 2: The level of a small technology firm's risk-taking behaviour is positively associated with the firm's performance.

\subsubsection{Proactiveness}

Proactiveness refers to a firm's approach to market opportunities through first-mover and other actions to secure and protect market share and participate in emerging markets (Miller, 1983; Covin and Slevin, 1991). Proactive firms are described as having an opportunity-seeking attitude to the market including introducing new products or services ahead of the competition and hence acting in anticipation to future demand. In high growth industries, like ICT, proactiveness could lead to a substantial growth opportunity for the firm. A formal representation of the above yields:

Hypothesis 3: The level of a small technology firm's proactiveness is positively associated with the firm's performance. 


\subsubsection{Impact on firm performance over time}

Some research suggests that the effect of entrepreneurial orientation on performance is long-term rather than short-term (Wiklund, 1999). Zahra and Covin (1995) have shown that the influence of entrepreneurial orientation on firm performance increases over time. These results suggest that entrepreneurial orientation should not be viewed as a short term "fix", but as a long-term strategy for achieving superior performance (Zahra and Covin, 1995). Given the multidimensional aspect of entrepreneurial orientation, this leads us to the following:

Hypothesis 4: The strength of the small technology firm's innovativeness - performance relationship will increase over time.

Hypothesis 5: The strength of the small technology firm's risk-taking-performance relationship will increase over time.

Hypothesis 6: The strength of the small technology firm's proactiveness - performance relationship will increase over time. 


\section{RESEARCH METHOD}

This chapter is organized into seven sections. The first section describes the unit of analysis and defines small firm. Section two describes the data sources. Section three presents the data collections methodology. Section four defines the sampling period. Section five presents variable operationalization approaches. Section six addresses common method variance while the last section introduces the data analysis technique.

\subsection{Unit of Analysis}

The unit of analysis is a small firm that develops technology products and services and classified under North America Industry Classification Systems, 2002.

\subsubsection{Defining a small firm}

Several characteristics are used to define a firm as "small" including: size by number of employees, sales volume, asset size, type of customer, and capital requirements (Ibrahim and Goodwin, 1986). Literature does not provide consensus as to what constitutes a small firm. However, the European Network of Social and Economic Research as well as Industry Canada (Small Business Research and Policy, Catalogue number Iu86-1/72006E) have adopted a definition based on number of employees and provided the following grouping:

- Micro: One to nine employees

- Small: Ten to ninety nine employees 
- Medium: One hundred to four hundred and ninety nine employees

- Large: Five hundred or more employees

For the purpose of this study we define a small technology firm as a firm that develops technology products and services and employs one to ninety nine employees at the beginning of the study period in 1999 .

\subsection{Data Sources}

The population of this study is technology-intensive small Canadian firms drawn from Statistics Canada Workplace and Employee Survey (WES) database. WES is designed to explore a broad range of issues relating to firms and their employees (Statistics Canada, catalogue number 71-221-GIE). The survey aims to shed light on the relationships among competitiveness, innovation, technology use and human resource management on the employer side and technology use, training, job stability and earnings on the employee side.

WES was conducted for the first time in 1999. The survey frame is created from the information available on the Statistics Canada Business Register. The firm sample is longitudinal - the sampled locations are followed over time. This longitudinal aspect allowed the current study to examine firm performance over time. 
Prior to sample selection, the business locations on the frame are divided into relatively homogeneous groups called strata, which are then used for sample allocation and selection. The WES frame is segmented by industry (14), region (6), and size (3, estimated employment). The size strata boundaries are typically different for each industry/region combination. The cut-off points defining a particular size stratum are computed using a model-based approach. The sample is selected using Neyman allocation (Cochran, 1977). This process partitions the target population into 252 strata. In 1999, 9,043 business locations were selected. In 2001, 1,792 locations were added for a total of 10,815 . In $2003,2,334$ locations were added for a total of 13,149 business locations.

Statistics Canada takes great care to respect the trust of their respondents and to safe guard the privacy and confidentiality of the information that they provide. As a result, Disclosure Avoidance Guidelines for using the WES survey are strictly enforced. The goal of disclosure avoidance is to protect the information provided by respondents while presenting the least possible hindrance to research. Disclosure avoidance covers the following types of data disclosures:

- Residual disclosure occurs when information about a respondent firm can be detected from the current information and previous information released. This is a particular problem with longitudinal data when age, size and revenues of the firm are released in subsequent cycles. 
- Identity disclosure occurs when a specific firm can be identified from the released data (e.g., a large firm in a particular industry focused on a specific market segment such as telecommunications).

- Attribute disclosure occurs when confidential information is revealed and can be attributed to a firm (e.g., small firm in ICT sector in a small locality or niche market).

- Direct identifiers such as name, address or telephone number that provides explicit link to a firm.

- Indirect identifiers such as type of business, size, age, or location, etc., that can be used to identify a firm.

Statistics Canada offered this researcher the 'Remote Access Service' to permit the use of Workplace and Employee Survey (WES) database in this research. The remote access service requires the researcher to submit a proposal to Statistics Canada that is academic in nature (non-commercial) and uses multivariate methods. Once the proposal is reviewed and approved, Statistics Canada sends a 'dummy data set' that allowed the researcher to write and debug analysis program in SAS. The researcher then submits syntax files for producing analytic results from the WES microdata files. The analytic results are screened by Statistics Canada for potential risk of disclosure, and only analytic results that are free from any potential risk of disclosing confidential information are returned to researcher. 


\subsection{Data Collection}

Responding to WES survey is mandatory. Data are collected directly from survey respondents. Data collection, data capture, preliminary editing and follow-up of nonrespondents are all done in Statistics Canada Regional Offices. In 1999, firm data were collected in person. Since 2000, computer assisted telephone interviews are conducted. For about $20 \%$ of the surveyed units (mostly large workplaces), more than one contact person is required. Following collection, all data are analyzed extensively and crossreferenced with other business data available in Statistics Canada. Extreme values are listed for manual inspection in order of priority determined by the size of the deviation from average behaviour.

To maximize the usability of the collected information, three principal activities, editing, outlier detection and imputation, have been deployed in the WES database to ensure that the final data be of the highest quality. Editing is an interactive process whereby the respondent is asked to confirm information that either appears suspect or does not follow some pre-specified general rules governing the data to be collected. This process takes place in the field during data collection. The detection of outliers is a statistical technique used to identify anomalous responses that either evaded edits, or that did not confirm to the correlation structure of the majority of data. Imputation is a statistical technique used to fill information that the respondent fails to provide. 
The firm questionnaire in the WES survey contains nine blocks. Each block focuses on a different theme such as Workforce Characteristics, Compensation, Firm Performance, Business Strategy, Innovation and Training. This research draws its data from Business Strategy, Firm Performance, Innovation and Workforce Characteristics. In most cases a single respondent will be able to answer all questions. If the primary respondent is unable to provide the requested information in its entirety, then he or she will be asked by Statistic Canada to identify the person privy to this information.

\subsection{Sample Period}

This study examines firm's performance between 1999 and 2002. The survey is longitudinal, so the same firms are followed within that period of time.

\subsection{Variable Operationalization}

Researchers studying entrepreneurial orientation have used three main operationalization approaches: (1) management perceptions; (2) firm behaviour; and (3) resource allocations.

Management perceptions of firm-level variables such as performance and strategy are often used in entrepreneurial orientation research. Perceptions can be obtained from interviews or surveys. Miller (1983) and Covin and Slevin (1988; 1989) have used survey-type measures in their research by posing questions that address directly the 
underlying nature of the construct. Measures of perceptions, however, may lack internal consistency due to functional bias when multiple respondents are involved in the survey.

Covin and Slevin (1991) noted that conceptualizing entrepreneurial orientation as firm behaviour has several advantages: a) firm behaviour such as the introduction of new or improved products or services or expansion into a new territory can be directly observed and measured; b) firm behaviour can be managed though the creation of particular strategies, structures and other organizational phenomena, thereby making it open to managerial intervention and control.

A number of researchers have suggested examining firm resource allocations to operationalize entrepreneurial orientation. Resource allocation measures, such as expenditures or the percentage of professionals and engineers relative to the total number of employees in the firm, can be compared across time and across firms. Archival measures such as firm financial data and organization demographics are easy to confirm.

This research uses both firm behaviour and resource allocations approaches to operationalize the variables.

\section{Innovativeness}

Professional employees such as scientist and engineers possess the knowledge and training that often make them most capable and motivated to discover new products and processes (Miller and Friesen, 1982). Following suggestions of Miller (1983) and Covin 
and Slevin (1991), RandD intensity was used as a proxy for innovativeness of the firm. RandD intensity is measured as the number of technical and professional employees in 1999 divided by the total number of firm's employees in the same year. Figure 4 defines innovativeness and the approach taken to operationalize the variable.

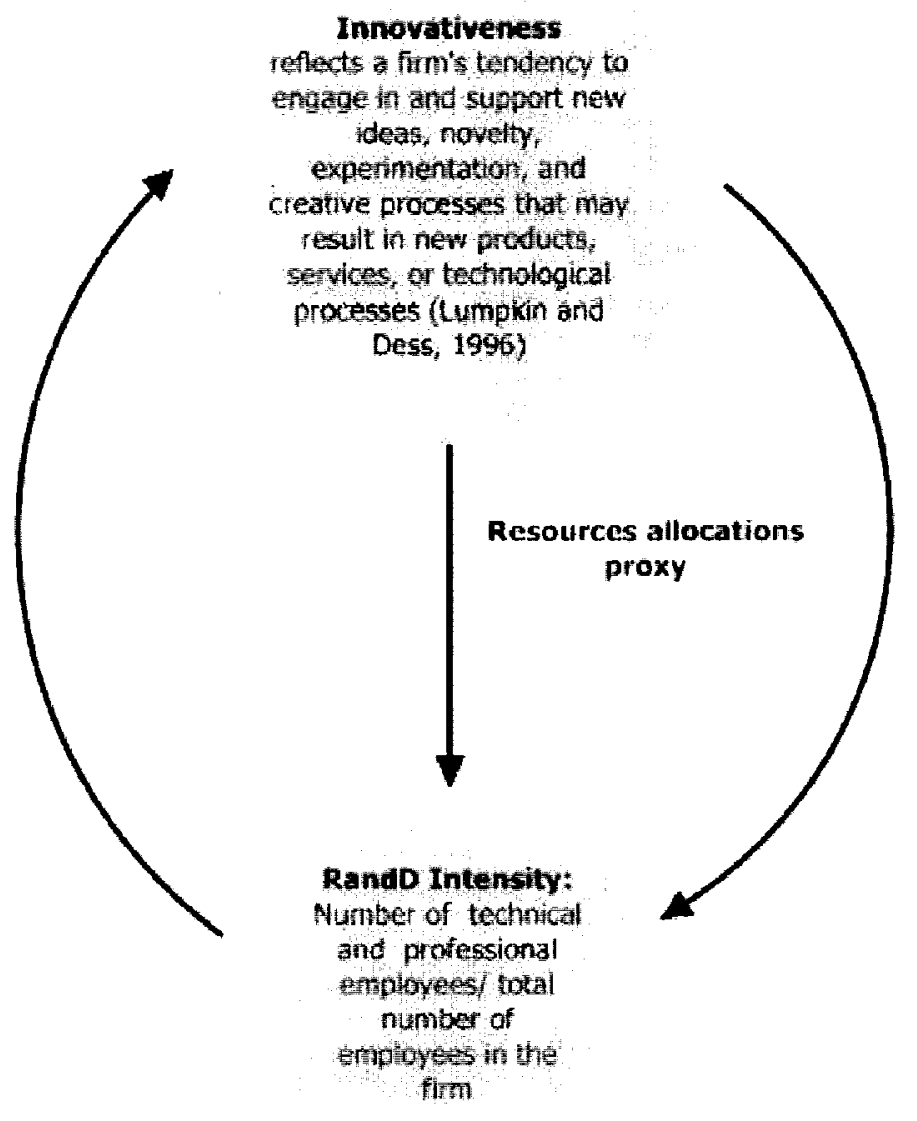

Figure 4. Operationalization of innovativeness 


\section{Risk-taking}

Risk-taking is associated with a willingness to commit more resources to projects where the cost of failure might be high (Miller and Friesen, 1982). It also implies committing resources to entering unknown markets (Lyon, Lumpkin and Dess, 2000). According to McDougall and Oviatt (2000), risk-taking firms pursue opportunities that cross national borders and are intended to create value. Several researchers have found that moving into new geographical markets, through international diversification, has positive effect on firm performance (e.g. Hitt, Hoskisson, and Kim, 1997). Firm's diversification into new geographical markets is consonant with the definition of risk-taking behaviour. International diversification of the firm is used as a measure for risk-taking. The most common form for measuring international diversification has been a unidimensional measure of international sales as a percentage of total sales (Hitt, Hoskisson, and Kim, 1997). We use the percentage of international sales relative to the firm's total sales as a measure of the firm's risk-taking behaviour. Figure 5 defines risk-taking and the approach taken to operationalize the variable. 


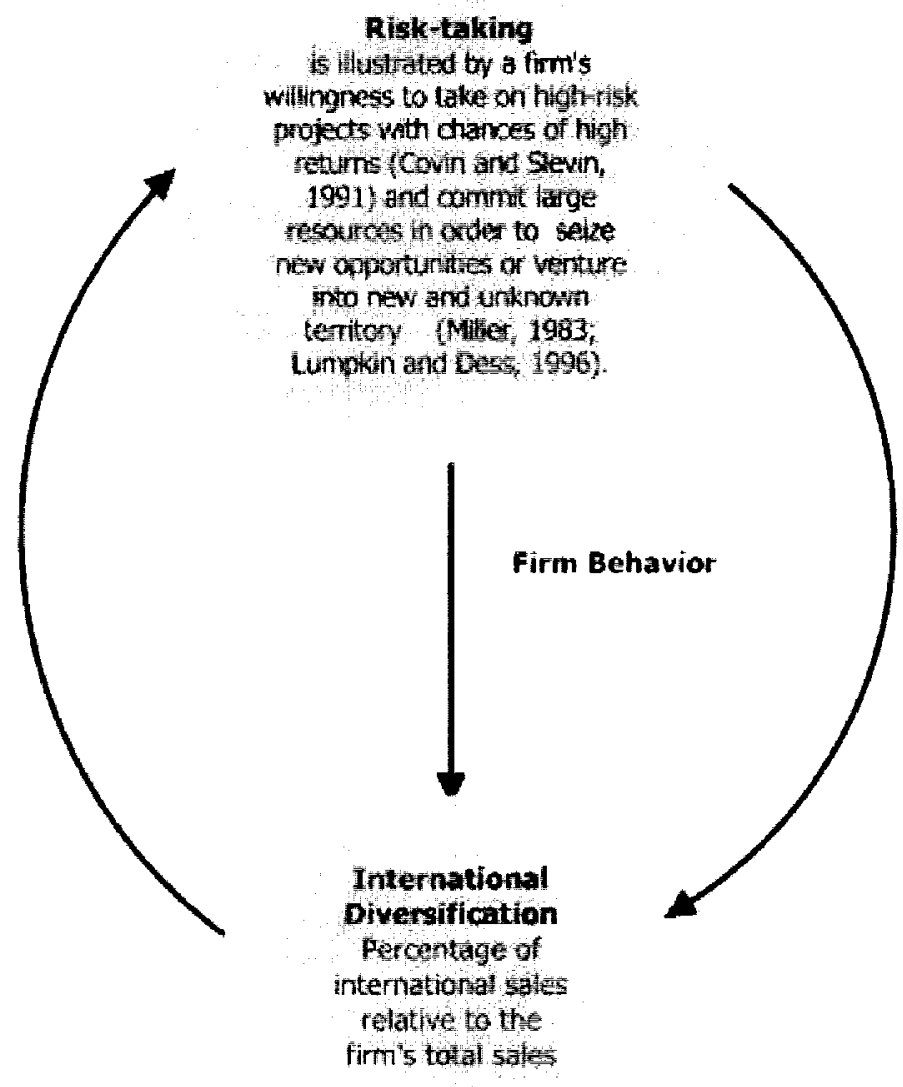

Figure 5. Operationalization of risk-taking

\section{Proactiveness}

Entrepreneurial firms often initiate actions to which competitors then respond, and are frequently first-to-market with new product offerings (Covin and Slevin, 1991).

Proactiveness describes first mover action related to new product introduction. We use the action taken by the firm to introduce new or improved products or services that are Canadian or World first as a measure of its proactiveness. This variable has two values; " 0 " if the firm did not introduce new or improved products or services in 1999 or " 1 " if 
the firm introduce new or improved products or service in 1999. Figure 6 defines proactiveness and the approach taken to operationalize the variable.

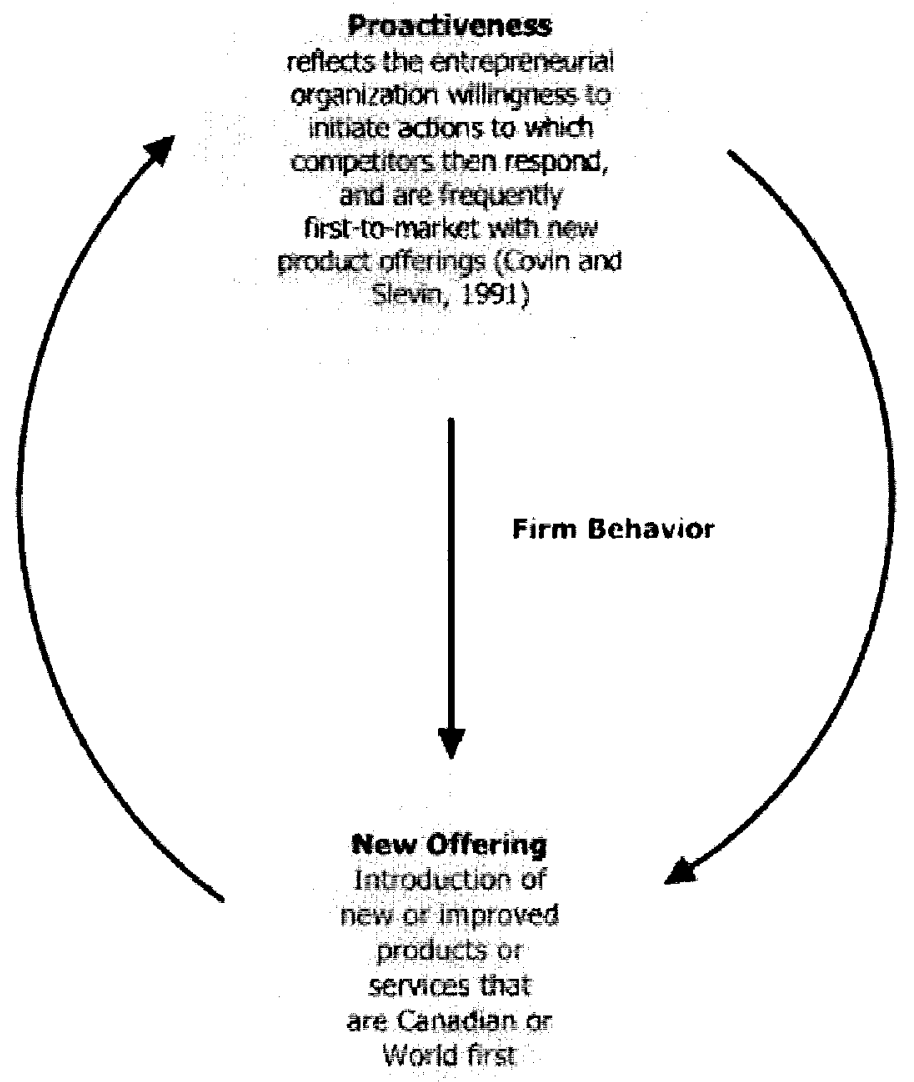

Figure 6. Operationalization of proactiveness 


\section{Performance}

Since a firm's growth process is likely to be driven by increased demand for the firm's products or services, revenues should naturally increase first, thus allowing for the acquisition of additional resources such as employees or equipment. Hoy, McDougall, and D'Souza (1992) identified revenue growth is the best growth measure for a firm. It reflects both short- and long-term changes in the firm. Furthermore, the authors maintain that entrepreneurs consider revenue growth to be the most common performance indicator. Revenue resulting from the sales and rental of all products and services was used as a measure of small firm performance.

Due to the Disclosure Avoidance Guidelines stipulated by Statistics Canada, firm revenue was provided as a categorical variable indicating if a firm's revenue resulting from the sales and rental of all products and services has increased, remained the same, or decreased compared to the previous year. Table 1 lists the different values of performance as a categorical variable.

\begin{tabular}{cc}
\hline Firm's Performance as & Value \\
a Categorical Variable & \\
\hline Increased & 1 \\
Remained the same & 0 \\
Decreased & -1 \\
\hline
\end{tabular}

Table 1. Performance as a categorical variable 
The categorical variable was calculated based on the actual change in revenue reported by the firm during data collection period and cross referenced with other business data available in Statistics Canada.

\subsection{Common Method Variance}

It has been stated that the relationships between variables measured with the same method, such as self-report surveys similar to the one used in this research, are inflated due to the effect of Common Method Variance (CMV). A number of authors have noted that the CMV problem is overstated. For example, Doty and Glick (1998) conducted meta-analysis on data from 28 multi-source studies comparing mono-method (selfreporting) versus multi-method correlations on measures of the same construct. They estimated that on average, method variance biased observed correlations among the underlying constructs by $26 \%$, which they concluded did not necessarily invalidate the conclusions based on mono-method results. Chandler and Hanks (1993) examined the self-reports of owners or chief executives of small firms and found that owner/CEO assessment of business volume (sales performance, earnings) was highly correlated with archival sales figures.

There are a number of design strategies that can be helpful in reducing the effect of CMV biases. For example, measures that are dependent on factual information, such as whether the firm have expended into a new geographical markets or the total number of professional workers employed by the firm, might be relatively resistant to most biases. 
Time can also be an effective means of controlling occasion factors that influence measurement at a given point in time (Spector, 2006). Assessing variables over time using longitudinal studies can help reduce such biases. Both strategies have been deployed in this research.

\subsection{Analytical Technique}

Hypotheses 1 to 3 attempt to establish the relationship between each of the entrepreneurial orientation dimensions and firm's performance at the start of the sampling period. Hypotheses 1 to 3 do not have a temporal component. That is, the relation between performance and each of the components of entrepreneurial orientation is assumed to have no delay. Improved performance in 1999 is a response to innovativeness, proactiveness, and risk taking in 1999. The proper representation of the regression would be as follows:

$$
\begin{aligned}
& \mathrm{P} 99=\alpha 1+\lambda 1^{*} \text { size }+\mu 1 * \text { age }+\beta 1 * 199+\text { residual } \\
& \mathrm{P} 99=\alpha 2+\lambda 2^{*} \text { size }+\mu 2 * \text { age }+\beta 2 * \mathrm{R} 99+\text { residual } \\
& \mathrm{P} 99=\alpha 3+\lambda 3^{*} \text { size }+\mu 3^{*} \text { age }+\beta 3 * \mathrm{~V} 99+\text { residual }
\end{aligned}
$$

where:

P99 = Measure of firm's performance in 1999

I99 = Measure of firm's innovativeness in 1999

$\mathrm{R} 99$ = Measure of firm's risk-taking in 1999

V99 $=$ Measure of firm's proactiveness in 1999 
Hypotheses 4 to 6 investigate the relationships between firm performance and each of the entrepreneurial orientation dimensions over time. Hypotheses 4 to 6 have a temporal component. They allow for the fact that it may take time before revenue growth responds to the occurrence of the entrepreneurial orientation dimension. That is, if the entrepreneurial behaviour takes place in 1999, improved performance may not occur in a measurable sense until 2000, 2001, etc.

Following the lead of Zahra and Covin (1995), testing of hypothesis 4 proceeded by first regressing the second year's firm performance in 2000 with innovativeness measured in 1999 (start of the sample period). Then, the third's year performance in 2001 was regressed on 1999 measure of innovativeness, and so on.

$$
\mathrm{P} 99+\mathrm{t}=\alpha 4+\lambda 4^{*} \text { size }+\mu 4 * \text { age }+\beta 4 * 199+\text { residual, } \mathrm{t}=1 \ldots 3
$$

Testing of hypothesis 5 proceeded by regressing the second year's firm performance in 2000 with risk-taking measured in 1999 (start of the sample period). Then, the third's year performance in 2001 was regressed on 1999 measure of risk-taking, and so on.

$$
\mathrm{P} 99+\mathrm{t}=\alpha 5+\lambda 5^{*} \text { size }+\mu 5^{*} \text { age }+\beta 5^{*} \mathrm{R} 99+\text { residual, } \mathrm{t}=1 \ldots 3
$$

Testing of hypothesis 6 proceeded by regressing the second year's firm performance in 2000 with proactiveness measured in 1999 (start of the sample period). Then, the third's year performance in 2001 was regressed on 1999 measure of proactiveness, and so on.

$$
\mathrm{P} 99+\mathrm{t}=\alpha 6+\lambda 6^{*} \text { size }+\mu 6^{*} \text { age }+\beta 6^{*} \mathrm{~V} 99+\text { residual, } \mathrm{t}=1 \ldots .3
$$


All firms in the sample had between one and ninety-nine employees at the start of the sampling period. All firms in the sample were classified under the North American Industry Classification System (NAICS) as manufacturing firms operating in the ICT sector.

Based on the results of testing hypothesis 1 to 6 , the value of $t$ (where response of revenue to firm behaviour is most pronounced) will be specified. That is, it can take a value between 0 and 3: 0 (if response of revenue is instantaneous to incidence of entrepreneurial orientation dimensions in 1999), 1 (if response of revenue lags one year behind incidence of entrepreneurial behaviour in 1999), etc. The time $t$ where revenue growth responds to entrepreneurial behaviour in 1999 will be denoted hereafter as $t^{*}$.

Since the dependent variable in this research (firm performance) is a categorical variable, the assumption of a normal distribution (a necessary assumption for linear ordinary least squares regression) is no longer valid. For categorical response variables, there is a diversity of analysis techniques. The one applied in this paper is logistic regression. The logistic regression analysis is used to investigate the relationship between firm performance in consecutive years for which data are available $(\mathrm{P} 99+\mathrm{t})$ and the dimensions of entrepreneurial orientation (innovativeness, risk-taking and proactiveness).

Logistic regression can be used when the dependent variable is categorical. The regression was first used with binary dependent variables, but the formulation of the model was then extended to include multi-category variables as well. There are two 
types of categorical variables: nominal and ordinal. Nominal categorical variables have categories, with no ordering significance. That is, the values assigned within the variable bear no significance except to distinguish between the different possible values that the variable can attain. In the regression model of a variable with $m$ categories, estimates $\left(\beta_{\mathrm{i}}\right.$, $\mathrm{i}=1, \ldots, \mathrm{m}-1$ ) are produced for $\mathrm{m}-1$ categories relative to the reference level (the omitted $\mathrm{m}^{\text {th }}$ category). On the other hand, ordinal categorical variables are categorical variables where the ordering of the variables is meaningful, even though the actual values in the categories may not be. That is, an ordinal variable with categories $(-1,0,+1)$ indicates that

$$
\mathrm{P}(\mathrm{Y} \leq-1) \leq \mathrm{P}(\mathrm{Y} \leq 0) \leq \mathrm{P}(\mathrm{Y} \leq+1)
$$

In this model, firm's performance variable has the following values:

$$
\begin{array}{lr}
\text { Increased } & +1 \\
\text { Unchanged } & 0 \\
\text { Decreased } & -1
\end{array}
$$

The logit function uses all the three response categories collapsing the response into a binary outcome (Agresti, 1990), with only one estimate provided. In that case, the results of the model yield one parameter estimate $\beta$ that defines the relation between $\mathrm{Y}$ and $\mathrm{X}$.

While linear regressions yield parameter estimates, logistic regressions estimate the probability of a certain event occurring relative to that same event not taking place. That is, it estimates the odds of success versus failure, survival versus death, etc. In this case, the odds ratio would represent the relative probability of small firms in the ICT sector possessing a specific dimension of entrepreneurial orientation (innovativeness, risk- 
taking or proactiveness). Odds ratio can vary from 0 to infinity. If the odds ratio is one, there is no association between the variables under examination.

Odds Ratio Interpretation is an exponential relationship, $\mathrm{e}^{\beta}$, which provides an interpretation for the change in the probability per unit change in the explanatory variable (Agresti, 1990). For example, odds ratio interpretation $\left(e^{\beta}\right)=1.64$ indicates for each unit increase in the explanatory variable, there is $64 \%$ increase in the dependent variable.

The estimation process is done using weighted logistic regression analysis, as per the recommendation of Statistics Canada to accommodate the ordinal categorical dependent variable representing firm's performance. In the model, each firm in the database represents not only itself, but a number of other firms that fit a well defined profile. The weight assigned to a firm in the sample reflects the number of firms it represents, their importance within the sector, as well as the properties of the sample design of the WES survey. The logit function incorporates the weights into the estimation process and thus yields a picture that is much closer to the actual behaviour and characteristics of the population of small firms in the ICT sector. Design based weighting takes not only the weight variable into account, but the stratification design as well. Doing so can produce smaller standard errors which in turn increases the magnitude of the test-statistics. The higher test statistics is represented further to the right on the Chi Square distribution curve. The remaining area to the right thus becomes very small, yielding values of $p$ that are also small. 
Likelihood ratio (LR) method has been used to perform significance tests for hypotheses $\mathrm{H} 0: \beta=0$. The significance tests examine the possibility that there is no relation between the dependent and independent variables. Thus, the null hypothesis testing the significance of the estimated odds ratio $\left(\mathrm{e}^{\mathrm{B}}\right)$ is formulated as:

$$
\begin{aligned}
& \text { Ho: } \boldsymbol{\beta}=0 \rightarrow \mathrm{e}^{\boldsymbol{B}}=\mathrm{e}^{0} \\
& \rightarrow \mathrm{e}^{\mathfrak{B}}=1 \\
& \rightarrow \text { All events are equally likely } \\
& \rightarrow \text { Independent variables do not influence dependent } \\
& \text { Variable }
\end{aligned}
$$

The test determines the parameter values that maximize the likelihood function under the assumption that $\mathrm{H} 0$ is true (Agresti, 1990). It also determines the values that maximize it under the more general condition that $\mathrm{H} 0$ may or may not be true. The test is based on the ratio of the maximized likelihoods,
$\Lambda=$ maximum likelihood when parameters satisfy $\mathrm{HO}$ maximum likelihood when parameters are unrestricted 


\section{RESULTS}

This chapter is organized in five sections. The first section describes the sample data. The second section presents the logistic regression analysis results for the total sample. Section three presents the regression results for the product and service categories within the sample. Section four presents Pearson correlation results. Section five discusses the external validity and generalization of this research.

\subsection{Sample}

The sample consisted of 63 firms operating in the Information and Communications Technologies sector. The firms were selected based on the North American Industry Classification System (NACIS). The 63 firms were all in operation at the start of 1999 and continued throughout the sample period. Figure 7 shows the firms' age distribution in the sample in 1999. 


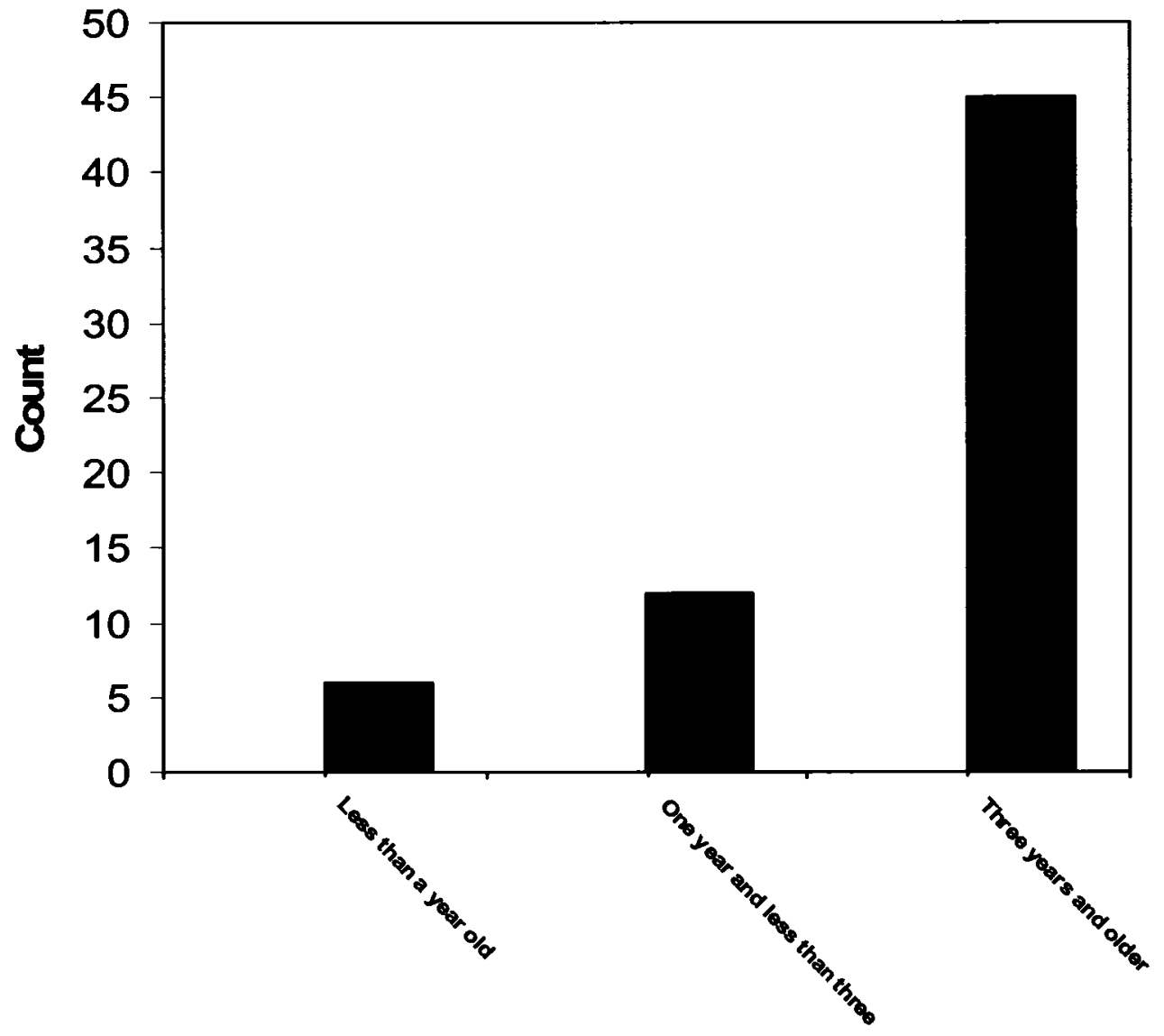

Firm Age in years in 1999

Figure 7. Firms in the sample sorted by age

Figure 8 shows firms in the sample sorted by the ICT sector. 


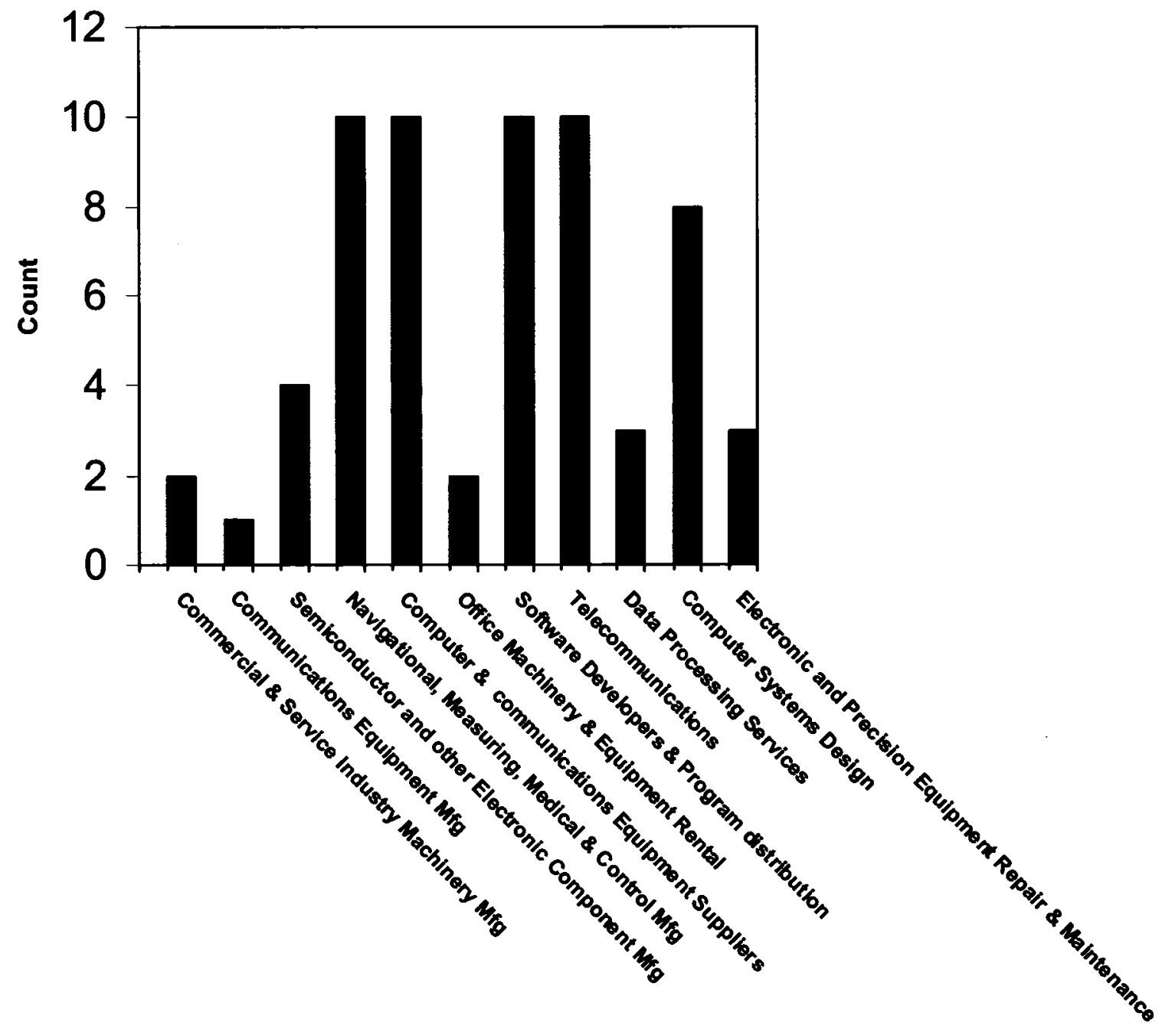

ICT sectors

Figure 8. Firms in the sample sorted by sector 


\subsection{Logistic Regression Results}

Table 2 shows the logistic regression analysis results based on the sample of 63 firms operating in the Information and Communications Technologies sector. The 1999 column shows the results for hypothesis H1, H2 and H3. The 2000, 2001 and 2002 columns list the results for hypothesis H4, H5 and H6. The Likelihood Ratio (hereafter referred to as LR) of hypotheses $H 0: \beta=0$ is provided as a statistical test for the goodness-of-fit.

Odds Ratio Interpretation

\begin{tabular}{|c|c|c|c|c|}
\hline \multirow[b]{2}{*}{ Variables } & \multicolumn{4}{|c|}{ Performance } \\
\hline & 1999 & 2000 & 2001 & 2002 \\
\hline Innovativeness & $\begin{array}{c}1.019 \\
(p<0.0001) \\
L R=1952.5183\end{array}$ & $\begin{array}{c}1.042 \\
(p<0.0001) \\
L R=3416.6146\end{array}$ & $\begin{array}{c}1.039 \\
(p<0.0001) \\
L R=3774.9396\end{array}$ & $\begin{array}{c}1.046 \\
(p<0.0001) \\
L R=3182.0547\end{array}$ \\
\hline Risk-taking & $\begin{array}{c}1.006 \\
(p<0.0001) \\
L R=1495.4131\end{array}$ & $\begin{array}{c}1.026 \\
(p<0.0001) \\
L R=85.0493\end{array}$ & $\begin{array}{c}1.017 \\
(p<0.0001) \\
L R=573.1999\end{array}$ & $\begin{array}{c}0.990 \\
(p<0.0001) \\
L R=953.6292\end{array}$ \\
\hline Proactiveness & $\begin{array}{c}1.029 \\
(p<0.0001) \\
L R=2917.8872\end{array}$ & $\begin{array}{c}1.315 \\
(p<0.0001) \\
L R=342.2566\end{array}$ & $\begin{array}{c}1.337 \\
(p<0.0001) \\
L R=594.0813\end{array}$ & $\begin{array}{c}1.161 \\
(p<0.0001) \\
L R=1451.7846\end{array}$ \\
\hline
\end{tabular}

Table 2. Logistic regression analytical results

Hypothesis 1 states that the level of small technology firm's innovativeness is positively associated with the firm's performance. Consistent with hypothesis 1 , the odds ratio interpretation of innovativeness is greater than one and statistically significant with firm performance in 1999 and over each year of the rest of the sampling period. Thus, consistent with hypothesis 4 , the strength of the small technology firm's innovativeness performance relationship increases over time. Figure 9 shows the results and trend line. 


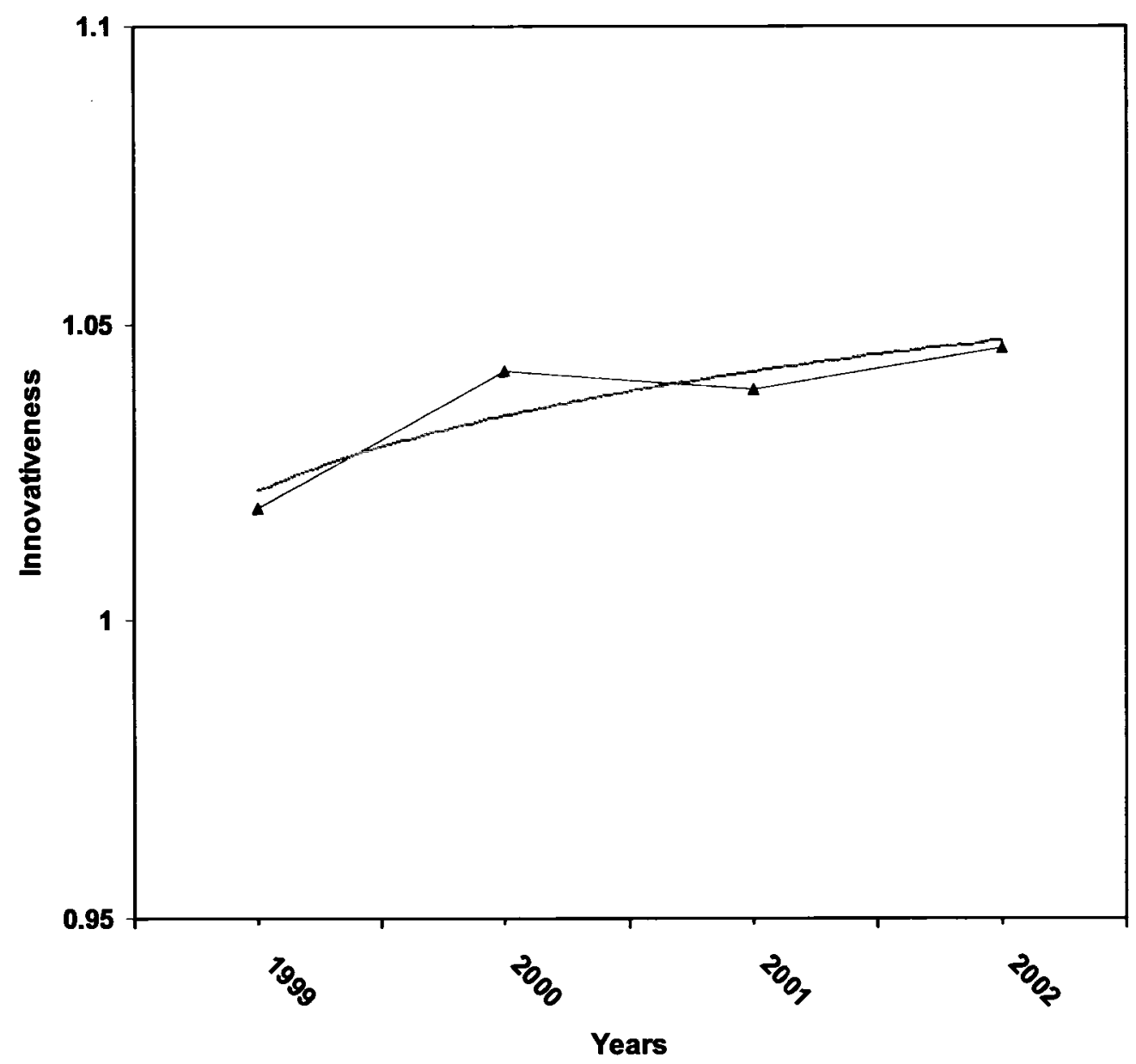

Figure 9. Innovativeness analysis

Hypothesis 2 states that the level of small technology firm's risk-taking is positively associated with the firm's performance. Consistent with hypothesis 2 , the odds ratio interpretation of risk-taking is greater than one and statistically significant with firm performance in 1999 and over each year of the rest of sampling period. Thus, consistent with hypothesis 5 , the strength of the small technology firm's risk-taking - performance relationship increases over time, peaking at year two and declining there after. Figure 10 shows the result and trend line. 


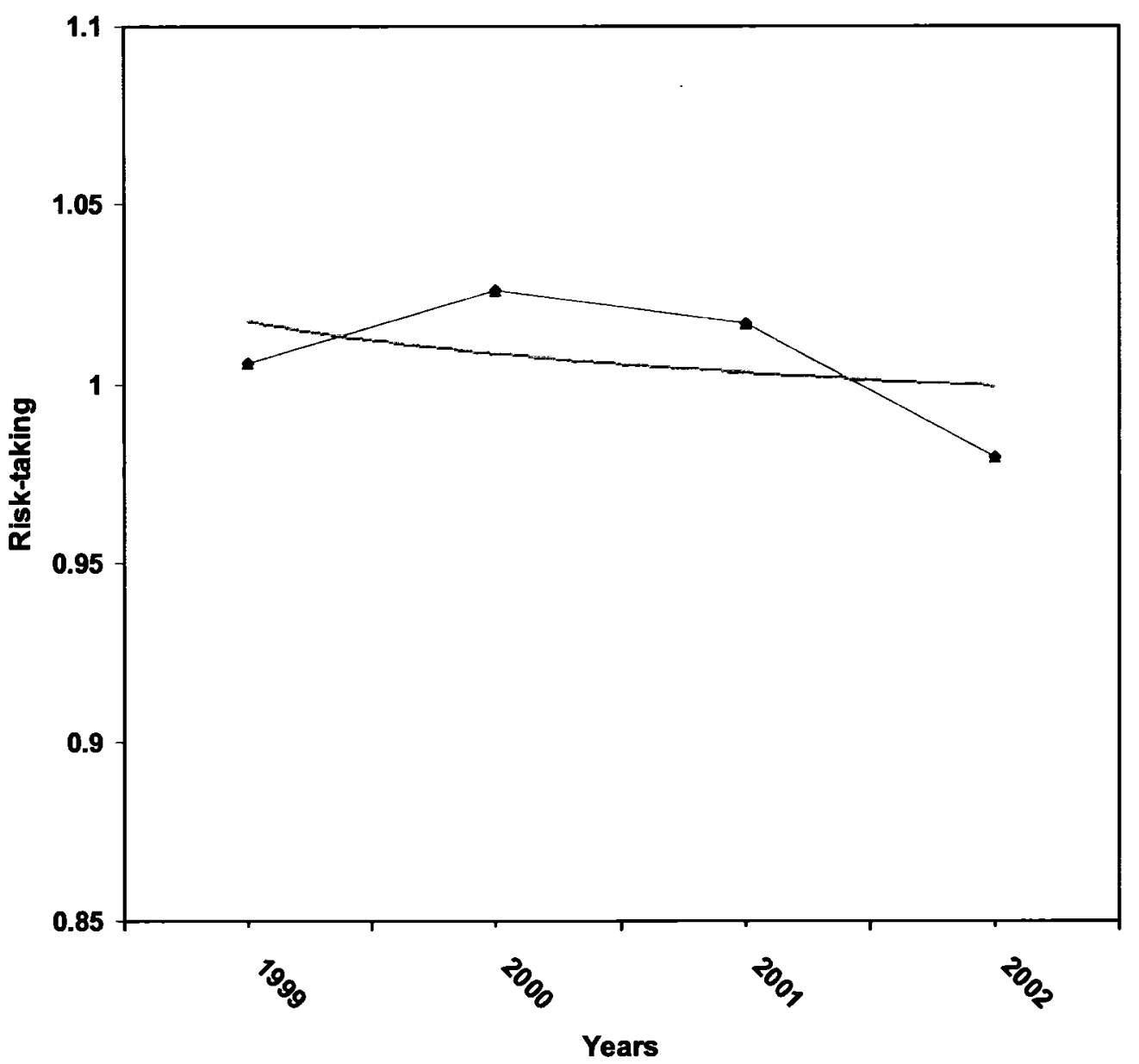

Figure 10. Risk-taking analysis

Hypothesis 3 states that the level of small technology firm's proactiveness is positively associated with the firm's performance. Consistent with hypothesis 3 , the odds ratio interpretation of proactiveness is greater than one and statistically significant with firm performance in 1999 and over each year of the rest of the sampling period. Thus, consistent with hypothesis 6 , the strength of the small technology firm's proactiveness - 
performance relationship increases over time, peaking at year three and declining there after. Figure 11 shows the results and trend line.

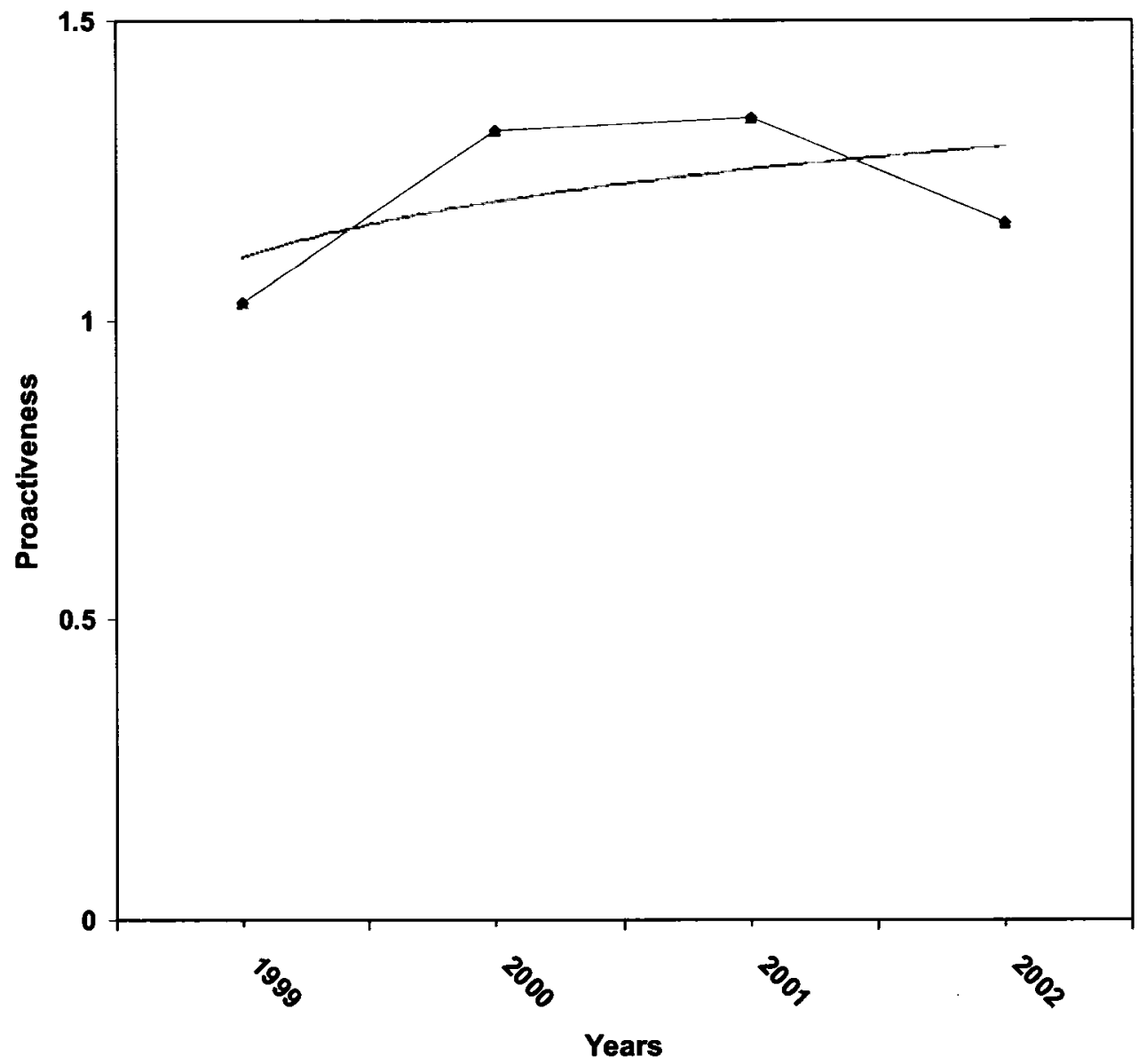

Figure 11. Proactiveness analysis

\subsection{Products and Services Analysis}

To further study the effect of entrepreneurial orientation dimensions on small firms in the ICT sector, the firms in the sample were divided into product and service categories using 
the North American Industry Classification System (NAICS) definition. The product category includes all firms engaged in manufacturing including software development and publishing, computer equipment manufacturing, telecommunication equipment manufacturing, semiconductor and other electronic component manufacturing. The service category includes all firms engaged in providing good related services such as computer and computer peripheral services as well as intangible services such as wireless telecommunications carriers, integration and information services (excluding software publishing) and data processing services. Hypotheses 1 to 6 were tested on each category separately and the results are presented below.

\subsubsection{Product Category Analysis}

Table 3 shows the logistic regression analysis results based on the sample of 22 Product Category firms operating in the Information and Communications Technologies sector. The 1999 column shows the results for hypothesis H1, H2 and H3. The 2000, 2001 and 2002 columns list the results for hypothesis H4, H5 and H6. The Likelihood Ratio (hereafter referred to as LR) of hypotheses $\mathrm{H} 0: \beta=0$ is provided as a statistical test for the goodness-of-fit. 


\section{Odds Ratio Interpretation}

\begin{tabular}{|c|c|c|c|c|}
\hline \multirow[b]{2}{*}{ Variables } & \multicolumn{4}{|c|}{ Performance } \\
\hline & 1999 & 2000 & 2001 & 2002 \\
\hline Innovativeness & $\begin{array}{c}1.005 \\
(p<0.0001) \\
L R=248.4395\end{array}$ & $\begin{array}{c}1.009 \\
(p<0.0001) \\
L R=119.1719\end{array}$ & $\begin{array}{c}1.011 \\
(p<0.0001) \\
L R=135.8020\end{array}$ & $\begin{array}{c}1.000 \\
(p<0.0001) \\
L R=669.9731\end{array}$ \\
\hline Risk-taking & $\begin{array}{c}1.011 \\
(p<0.0001) \\
L R=258.0423\end{array}$ & $\begin{array}{c}1.001 \\
(p<0.5055) \\
L R=105.1418\end{array}$ & $\begin{array}{c}1.003 \\
(p<0.1548) \\
L R=106.1229\end{array}$ & $\begin{array}{c}1.000 \\
(p<0.1567) \\
L R=787.4640\end{array}$ \\
\hline Proactiveness & $\begin{array}{c}1.030 \\
(p<0.0001) \\
L R=434.7927\end{array}$ & $\begin{array}{c}1.217 \\
(p<0.0001) \\
L R=131.3578\end{array}$ & $\begin{array}{c}1.073 \\
(p<0.8301) \\
L R=35.5392\end{array}$ & $\begin{array}{c}1.057 \\
(p<0.0858) \\
L R=492.3406\end{array}$ \\
\hline
\end{tabular}

Table 3. Logistic regression analytical results: product category

Hypothesis 1 states that the level of a small technology firm's innovativeness is positively associated with the firm's performance. Consistent with hypothesis 1 , the odds ratio interpretation of innovativeness is greater than one and statistically significant with firm performance in the product category in 1999, 2000, 2001 and equals 1 in 2002.

Thus, consistent with hypothesis 4 , the strength of the small technology firm's innovativeness - performance relationship increases over time, peaking at year 3 and declining afterwards.

Hypothesis 2 states that the level of a small technology firm's risk-taking is positively associated with the firm's performance. Consistent with hypothesis 2 , odds ratio interpretation of risk-taking is greater than one and statistically significant with firm performance in the product category in 1999 but statistically insignificant in 2000, 2001 and 2002. Thus, hypothesis 5 is not supported in this particular case. 
Hypothesis 3 states that the level of a small technology firm's proactiveness is positively associated with the firm performance. Consistent with hypothesis 3 , the odds ratio interpretation of proactiveness is greater than one and statistically significant with firm performance in the product category in 1999 and 2000 but statistically insignificant in 2001 and 2002. Thus, consistent with hypothesis 6 , the strength of the small technology firm's proactiveness - performance relationship increases over time, peaking at year 2 and becoming insignificant afterwards.

\subsubsection{Service Category Analysis}

Table 4 shows the logistic regression analysis results based on the sample of 41 Service Category firms operating in the Information and Communications Technologies sector. The 1999 column shows the results for hypothesis H1, H2 and H3. The 2000, 2001 and 2002 columns list the results for hypothesis H4, H5 and H6. The Likelihood Ratio (hereafter referred to as LR) of hypotheses $\mathrm{HO}: \beta=0$ is provided as a statistical test for the goodness-of-fit. 


\begin{tabular}{|c|c|c|c|c|}
\hline \multirow[b]{2}{*}{ Variables } & \multicolumn{4}{|c|}{ Performance } \\
\hline & 1999 & 2000 & 2001 & 2002 \\
\hline Innovativeness & $\begin{array}{c}1.015 \\
(p<0.0001) \\
L R=1679.3543\end{array}$ & $\begin{array}{c}1.078 \\
(p<0.0001) \\
L R=4757.8435\end{array}$ & $\begin{array}{c}1.046 \\
(p<0.0001) \\
L R=3717.4064\end{array}$ & $\begin{array}{c}1.083 \\
(p<0.0001) \\
L R=6573.4426\end{array}$ \\
\hline Risk-taking & $\begin{array}{c}1.001 \\
(p<0.9555) \\
L R=1565.6228\end{array}$ & $\begin{array}{c}1.323 \\
(p<0.0001) \\
L R=1007.6086\end{array}$ & $\begin{array}{c}1.010 \\
(p<0.0001) \\
L R=674.2930\end{array}$ & $\begin{array}{c}0.990 \\
(p<0.0001) \\
L R=1323.4958\end{array}$ \\
\hline Proactiveness & $\begin{array}{c}1.001 \\
(p<0.9412) \\
L R=1296.4575\end{array}$ & $\begin{array}{c}1.076 \\
(p<0.0001) \\
L R=779.2992\end{array}$ & $\begin{array}{c}1.104 \\
(p<0.0001) \\
L R=808.2485\end{array}$ & $\begin{array}{c}1.082 \\
(p<0.0001) \\
L R=1729.6560\end{array}$ \\
\hline
\end{tabular}

Table 4. Logistic regression analytical results: service category

Hypothesis 1 states that the level of a small technology firm's innovativeness is positively associated with the firm's performance. Consistent with hypothesis 1 , the odds ratio interpretation of innovativeness is greater than one and statistically significant with firm performance in the service category in 1999 and over each year of the rest of the sampling period. Thus, consistent with hypothesis 4 , the strength of the small technology firm's innovativeness - performance relationship increases over time.

Hypothesis 2 states that the level of a small technology firm's risk-taking is positively associated with the firm's performance. The odds ratio interpretation of risk-taking is positive and statistically insignificant with firm performance in the service category in 1999 but statistically significant in 2000, 2001 and 2002. Thus, hypothesis 2 is not supported in this particular case. Consistent with hypothesis 5, the strength of the small 
technology firm's risk-taking - performance relationship increases over time, peaking at year 2 and declining afterwards.

Hypothesis 3 states that the level of a small technology firm's proactiveness is positively associated with the firm's performance. The odds ratio interpretation of proactiveness is greater than one and statistically insignificant with firm performance in the service category in 1999 but statistically significant in 2000, 2001 and 2002. Thus, hypothesis 3 is not supported in this particular case. Consistent with hypothesis 6 , the strength of the small technology firm's proactiveness - performance relationship increases over time, peaking at year 3 .

\subsection{Correlation}

Table 5 provides Pearson Correlation Coefficients for innovativeness, risk-taking, size and age of the small firms in the IC sector. Performance and proactiveness are categorical variables and have not been included in the correlation analysis.

\begin{tabular}{ccccc}
\hline & Innovativeness & Risk-taking & Size & Age \\
\hline Innovativeness & 1.000 & 0.4128 & 0.5243 & 0.041 \\
& & $(\mathrm{p}<0.0500)$ & $(\mathrm{p}<0.0470)$ & $(\mathrm{p}<0.4739)$ \\
Risk-taking & 0.4128 & 1.00 & 0.132 & 0.0603 \\
Size & $(\mathrm{p}<0.0500)$ & & $(\mathrm{p}<0.3017)$ & $(\mathrm{p}<0.6647)$ \\
& 0.5243 & 0.132 & 1.000 & 0.022 \\
Age & $(\mathrm{p}<0.0470)$ & $(\mathrm{p}<0.3017)$ & & $(\mathrm{p}<0.6934)$ \\
& 0.041 & 0.0603 & 0.022 & 1.000 \\
& $(\mathrm{p}<0.4739)$ & $(\mathrm{p}<0.6647)$ & $(\mathrm{p}<0.6934)$ & \\
\hline
\end{tabular}

Table 5. Pearson Correlation Results 
The correlation between innovativeness and risk-taking (.41) is in line with Kreiser et al.'s (2002) findings. Based on data collected from 1,067 firms, Kreiser et al. (2002) used correlational analysis-based results to demonstrate that innovativeness, risk-taking and proactiveness display "significant independent variance" and should be treated as "unique" variables in the context of entrepreneurial orientation research. In their study, the correlation between risk-taking and innovativeness was .44; the correlation between risk-taking and proactiveness was .46 ; and the correlation between innovativeness and proactiveness was .49 .

\subsection{External Validity}

Shadish et al. (2002) defined external validity as the validity of interferences about whether the identified causal relationship is maintained over variations in person, settings, time, or treatment of variables. The authors distinguished between the terms "generalize to" and "generalize across". Generalizing to populations is a situation where the sample is randomly selected from the target population and thus the findings can be generalized to that population in confidence. Generalize across the populations is a situation where the findings are applied to populations, settings, or times that were not represented in the sample. Generalizing beyond the sample of the study should be based on the size and representativeness of the sample target population, analytic methods, setting and theoretical constructs (Shadish et al., 2002). 
Shadish et al. (2002) suggested a number of principals to guide researchers in their assessing the external validity of their research findings including:

- Assess the apparent similarities between research operations and the prototypical characteristics of the target of generalization;

- Rule out irrelevancies by identifying attributes of person, settings, treatments and outcome measures that do not affect generalization;

- Identify those features of people, settings, treatments, or outcomes of the study that limit generalization.

Based on the above, the results in this research can only be generalized across small Canadian ICT firms that are in operation. 


\section{CONCLUSIONS, LIMITATIONS, AND SUGGESTIONS FOR FUTURE RESEARCH}

This chapter has three sections. The first section presents the conclusions drawn from this research and highlights implications for managers, investors, government bodies and economic development corporation aiming to help small firms in the Canadian ICT sector grow and achieve longevity. The second section identifies the limitations of this research. Finally, the third section provides suggestions for future research along the lines of the concept of entrepreneurial orientation.

\subsection{Conclusions}

Founders and managers of small firms in the ICT sector reviewing business literature are likely to uncover many stories about the advantage of entrepreneurial orientation to the survival and growth of their firms. Covin (1991) argues that in dynamic and extremely competitive markets, such as ICT sector, entrepreneurial orientation dimensions could be essential for the firm's ultimate survivals and growth. The argument is no longer if small firms should adopt an entrepreneurial orientation stance and the general impact of such an action on the firm's performance.

What is less obvious is the impact of each the entrepreneurial orientation's dimensions on the firm performance and how sustainable that impact is over a period of time. Miller (1983) originally conceptualized entrepreneurial orientation as a unidimensional 
construct comprised of innovativeness, risk-taking and proactiveness as elements. Lumpkin and Dess (1996) later suggested that entrepreneurial orientation is a multidimensional construct where its subdimensions - innovativeness, risk-taking and proactiveness - can vary independently of one another. They urged future researchers to explore the independence of entrepreneurial orientation dimensions and their contingent relationships to performance. Executives and managers are always struggling with competing priorities, especially when the firm is still small and constrained by limited financial and human resources. It would help to know which entrepreneurial action can generate the highest return on effort and investment and when should the firm engage in an "another wave" of entrepreneurial actions to ensure sustainable growth over the years.

This research shows that the dimensions of entrepreneurial orientation have positive impact on small firm's performance, albeit with varying degrees. A unit increase in small firm's proactiveness in 1999 , represented by the action of introducing new or improved products and services, would result in $2.9 \%$ increase in the estimated odds in favour of improved performance in the same year. Similarly, a unit increase in the firm's innovativeness in 1999, measured by its RandD intensity, results in $1.9 \%$ increase in the estimated odds in favour of improved performance in the same year. The entrepreneurial action of risk-taking in 1999, represented by expanding into new markets, would result in a mere $0.6 \%$ increase in the estimated odds in favour of improved performance in the same year. The results show that the subdimensions of entrepreneurial orientation vary independently from one another as argued by Lumpkin and Dess (1996). 
In line with Zahra and Covin (1995) and Wiklund (1999) findings, the entrepreneurial actions taken by the firm today have an impact on the firm's performance for several years to come. Proactiveness, for example, enhances the firm's estimated odds of improving performance in the second and third year following the action by $31.5 \%$ and $33.7 \%$ respectively but declines in year four to $16.1 \%$. Risk-taking, on the other hand, has lower impact on the firm's estimated odds of improving performance in year two and three of $2.6 \%$ and $1.7 \%$ respectively. Innovativeness has a positive influence on the estimated odds over the 4 year sampling period with $4.2 \%, 3.9 \%$ and $4.6 \%$ increase in favourable odds in year two, three and four respectively. The results show that firms with entrepreneurial orientation traits must continue to engage in entrepreneurial actions over time to sustain their growth.

The research also shows that the impact of entrepreneurial orientation dimensions on firm's odds of improving performance varies depending on the firm's focus on product or services activities. The entrepreneurial activities of small firms in the ICT sector that are product oriented lead to a different impact on performance odds than their counterparts in the services sector. Risk-taking, for example, has little or no impact on firm's odds of improving performance in the product category during the study period. This may be attributed to the fact that building product superiority in new markets requires a much longer time. Risk-taking, however, has a higher impact on the firm's odds of improving performance in the service category. A unit increase in risk-taking exhibited by a small ICT firm in the service category increases the odds in favour of improved performance by $32.3 \%$ in year two, but quickly decline afterwards. On the other hand, a unit increase in 
proactiveness of a small firm in the product category results in a $21.7 \%$ increase in the firm's odds of improving performance in year two compared to just $7.6 \%$ for a firm in the service category. This shows that the introduction of new or improved products has higher impact in the product category than in the service category.

Innovativeness has a higher impact on the firm's odds of improving performance in the service category than in the product category. This shows that service oriented firms benefit more from increasing their RandD intensity by adding more technical and professional staff. That, in turn, tends to generate more revenues for the firm due to their consulting and integration knowledge as well as the higher intellectual content in services. Product oriented firms may not realize the full impact of increasing their RandD intensity without taking other entrepreneurial actions such as the introduction of new or improved products (proactiveness).

This research makes the following recommendations to founders, managers, investors, government bodies and economic development corporation aiming to help small firms in the Canadian ICT sector:

- Small Canadian ICT firms need to focus on RandD spending. Investing in RandD provides small firms with sustainable growth impact in subsequent years.

- It is critical for managers of small Canadian ICT firms to determine the right entrepreneurial orientation activities that suit their small firms. As shown in this study, the impact of entrepreneurial activities on firm's performance 
varies between product and service categories. For example, service-oriented ICT firms will realize a higher likelihood of improving performance due to their risk-taking activities in new markets faster than their counterparts in the product-focused category.

- Small Canadian ICT firms need to consciously engage in repeated entrepreneurial oriented behaviour. Entrepreneurial orientation dimensions can have a sustainable impact on the firm's performance and growth provided that the firm continues to engage in wave after wave of entrepreneurial activities. Introducing new and improved products may have a minor impact on the firm's performance unless the effort is complemented by some risktaking and proactiveness activities.

- Managers of small Canadian ICT firms must collect and maintain extensive data and models about their strategic initiatives and performance. Using data mining and modeling tools, managers, investors and other stakeholders can better analyse their firms' performance to determine the underlying activities that contribute to its rise and fall rather than just relying on proxies such as market share, brand equity and cost of sales. Revenues and performance are critical metrics based on which most of for-profit firms are evaluated by stakeholders and the market. Understanding them involves looking back in time at the different strategic and tactical actions taken by the firm that influenced the current state. A $10 \%$ increase in spending on risk-taking activities such as expanding in new markets may drive only a small percentage increase in revenue for a product oriented firm. 
- More attention should be directed towards helping small firms to identify and engage in broader entrepreneurial activities that accelerate their growth. Economic development cooperation and government bodies serving the ICT sector have focused their attention on nurturing entrepreneurs through incubator programs while helping them to identify and address the technical research need for small and medium firms. However, technology and innovation are important components in a much broader framework that encompasses many other entrepreneurial activities.

\subsection{Limitations}

This research is not without limitations. First, the study used data from the Canadian ICT sector to test the hypotheses. Thus, the results can not be extended to other countries or industry sectors without further research in other settings.

Second, the research has focused on small firms that survived during the sampling period. The study did not cover firms that existed in 1999 but folded in subsequent years.

Conducting similar research on small ICT firms that ended their operations during the sampling period may provide additional insights on the differences between the adoption of entrepreneurial orientation in successful and non-successful firms.

Third, due to the Disclosure Avoidance Guidelines stipulated by Statistics Canada, little is known about the actual structure, funding and operations of the small firms covered in 
this research. Thus, it would not be possible to reach conclusions regarding firm entrepreneurial orientation based on internal workings, structure or other unobservable variables within the scope of this research.

Forth, the research has a four year sampling period from 1999 to 2002 during which the technology market meltdown of 2001 took place. The time dependence of the results is a limitation that can be addressed by extending the sampling period to include more years or selecting a different sampling period.

\subsection{Suggestions for Future Research}

There are four suggestions for future research. First future research may consider the effect of autonomy and competitive aggressiveness, two additional dimensions proposed by Lumpkin and Dess (1996) to the entrepreneurial orientation construct, on small ICT firms. A similar longitudinal analysis of firm level data focusing on these two dimensions may help advance the research in entrepreneurial orientation.

Second, there is a need to explore different operationalizations of entrepreneurial orientation's dimensions to further advance our understanding of the concept and provide more accurate prediction to management. For example, firm's innovativeness embodies process, products, RandD expenditures and structure. Proactiveness may be measured by the speed of response to competitor action and other competitive activities such as price cutting. Risk-taking may include heavy borrowing and acquisitions of other firms. 
Third, greater diversity in the industry scope and geographical boundaries of the research are also needed. Most past research has used data collected form North American companies. Future researchers are urged to explore the impact of entrepreneurial orientation dimensions by collecting data from other countries. There is a need to understand how national cultures affect the adoption and implementation of entrepreneurial orientation dimensions.

Finally, case studies can help define the effect of the organizational conditions on the firm's entrepreneurial orientation and consequently, its performance. For example, the influence of top managers or founders, ownership structure and organizational internal culture could all affect the firm's entrepreneurial orientation. Future research can improve our understanding of entrepreneurial orientation construct by combining case studies and other research methodologies to investigate the many other factors that could influence it. 


\section{REFERENCES}

Acs, Z.J., and Audretsch, D.B. 1990. Innovation and small firms, The MIT Press, Cambridge, Massachusetts.

Agresti, A. 1990. Categorical data analysis, New York: John Wiley \& Sons, Inc.

Andrews, K.R. 1980. The concept of corporate strategy, Homewood, Ill.: Richard D. Irwin.

Audretsch, D.B. 2001. Research issues relating to structure, competition and performance of small technology based firms. Small Business Economics, 16(1): 37-51.

Audretsch, D.B. 1995. Innovation, growth and survival. International Journal of Industrial Organization, 13: 441-450.

Audretsch, D.B. 1991. New firm survival and the technological regime. The Review of Economics and Statistics, 60(3): 441-450.

Audretsch, D.B., and Mahmood, T. 1995. New firm survival: New results using a hazard function. The Review of Economics and Statistics, 77(1): 97-103.

Baldwin, J., Bian, L., Dupuy, R., and Gellatly, G. 2000. Failure rates for new Canadian firms: New perspectives on entry and exit. Catalogue \# 61-526-XPE. Statistics Canada, Ottawa, Canada.

Barney, J. B. 1986. Strategic factor markets: Expectation, luck, and business strategy. Management Science, 31: 1231-1241.

Barney. J. B. 1991. Firm resources and sustained competitive advantage. Journal of Management, 17: 99-120.

Begley.,T.M., and Boyd, D.P. 1987. Psychological characteristics associated with performance in entrepreneurial firms and smaller businesses. Journal of Business Venturing, 2(1): 79-93.

Bhidé, A, 2000. The origin and evolution of new businesses, Oxford University Press, New York, New York.

Birch, D.L. 1979. The job generation process. MIT, Cambridge Maas.

Chandler, A.D., Jr. 1962. Strategy and structure. Cambridge: The MIT Press.

Chandler, G.N., and Hanks, S.H. 1993. Measuring the performance of emerging business: A validation study. Journal of Business Venturing, 8: 391-408. 
Churchill, N.C., and Lewis, V.L. 1983. The five stages of small business growth. Harvard Business Review, repr. 83301.

Cochran, W.G. 1977. Sampling techniques, third edition. New York: Wiley.

Cooper, A.C. 1982. The entrepreneurship-small business interface. In: Kent CA, Sexton DL, Vesper KH (eds) Encyclopaedia of Entrepreneurship. Prantice-Hall, Englewood Cliffs NY, 193-208.

Cooper, A.C. 1971. Spin-offs and technical entrepreneurship. IEEE Transactions of Engineering Management, EM 18(1).

Cooper, A.C. and Atrz, K.W. 1995. Determinants of satisfaction of entrepreneurs. Journal of Business Venturing, 10(6): 439-457.

Covin, J.G. 1991. Entrepreneurial versus conservative firms. A comparison of strategies and performance. Journal of Management Studies, 28(5): 439-462.

Covin, J.G. and Slevin, D.P. 1988. The influence of organization structure on the utility of an entrepreneurial top management style. Journal of Management Studies, 25(3): 217 259.

Covin, J.G. and Slevin, D.P. 1989. Strategic management of small firms in hostile and benign environments. Strategic Management Journal, 10(1): 75-87.

Covin, J.G. and Slevin, D.P. 1991. A conceptual model of entrepreneurship as firm behaviour. Entrepreneurship: Theory and Practice, 16(1): 7-24.

Davidsson, P., Lindmark, L. and Olfosson, C. 1999. SMEs and job creation during a recession and recovery. Ch. 10 in Entrepreneurship, Small and Medium Sized Enterprises and the Macroeconomy, Cambridge, CUP.

Deeds, D.L., DeCarolis, D., and Coombs, J.E. 1998. Firm-specific resources and wealth creation in high-technology ventures: Evidence from newly public biotechnology firms. Entrepreneurship: Theory and Practice, 22: 55-73.

Dess, G.G., Beard, D.W. 1984. Dimensions of organizational task environments. Administrative Science Quarterly, 29(1): 52-73.

Dess, G.G., Lumpkin, G.T., and McGee, J.E. (1999). Linking corporate entrepreneurship to strategy, structure, and process: Suggested research directions. Entrepreneurship Theory and Practice, 23(3): 85-102.

Doty, D.H., and Glick, W.H. (1998). Common methods bias: Does common methods variance really bias results? Organizational Research Methods, 1: 374-406.

Drucker, P. F. 1985. Innovation and entrepreneurship. Harper and Row. 
Eisenhardt, K.M., Schoonhoven, C.B. 1990. Organizational growth: Linking founding team, strategy, environment and growth among US semiconductor ventures 1978-1988. Administrative Science Quarterly, 35: 504-529.

Evans, D.S. 1987a. The relationship between firm growth, size and age: estimating for 100 manufacturing industries. Journal of Industrial Economics, 35: 567-581.

Evans, D.S. 1987b. Tests of alternative theories of firm growth. Journal of Political Economy, 95: 657-674.

Ferrier, W. 2001. Navigating the competitive landscape: The drivers and consequences of competitive aggressiveness. Academy of Management Journal, 44(4): 858-877.

Hanks, S.H., Watscon, C.J, Jansen, E. and Chandler, G.N. 1993. Tightening the life-cycle construct: a taxonomic study of growth stage configurations in high-technology organizations, Entrepreneurship Theory and Practice, 18(2): 5-29.

Hart, P.E. and Oulton, N. 1996. Growth and size of firms. Economic Journal, 106: 12421252.

Hart, O., and Moore, J. 1999. On the design of hierarchies: Coordination versus specialisation, NBER working paper, 7388.

Hart, S.L. 1992. An integrative framework for strategy-making processes. Academy of Management Review, 17(2): 327-351.

Henderson, R. 1994. The evolution of integrative competence: Innovation in Cardiovascular drug discovery. Industrial and Corporate Change, 3(3): 607-30.

Hitt, M.A., Hoskisson, R.E, Kim, H. 1997. International diversification: effects on innovation and firm performance in product diversified firms. Academy of Management Journal, 6(3): 273-293.

Hornaday, J.A. 1982. Research about living entrepreneurs. In C.A. Kent, D.L.Sexton, and K.H.Vesper, eds., Encyclopaedia of Entrepreneurship. Englewood Cliffs, NJ.: PrenticeHall, 26-27.

Hoy, F., McDougall, P. P., and D'Souza, D. E. (1992). Strategies and environments of high growth firms. In D. L. Sexton and J. D. Kasarda (Eds.), The State of the Art of Entrepreneurship, 341-357. Boston: PWS-Kent.

Ibrahim, A.B., and Goodwin, J.R. 1986. Perceived causes of success in small business. American Journal of Small Business, 11(2): 41-50.

Industry Canada, Small Business Research and Policy, Key Business Statistics. June 2006. http://strategis.ic.gc.ca/epic/internet/insbrp-rppe.nsf/en/rd02024e.html. 
Industry Canada, Canadian ICT Sector Profile. March 2007.

http://strategis.ic.gc.ca/epic/site/ict-tic.nsf/vwapj/0107229e.pdf/\$FILE/0107229e.pdf.

Kelley, D. J. and Rice, M. P. 2002. Advantage beyond founding the strategic use of technologies. Journal of Business Venturing 17(1): 41-57.

Khandwalla, P.N. 1977. The design of organizations, New York: The Free Press.

Khandwalla, P.N. 1987. Generators of pioneering-innovative management: Some Indian evidence. Organization Studies, 8(1): 39-59.

Kirchoff, B., and Phillips, B. 1989. Innovation and growth among new firms in the U.S. Economy. Frontiers of Entrepreneurship Research. 173-88.

Kreiser, P.M., Marion, L.D., and Weaver, K.M. 2002. Assessing the psychometric properties of the entrepreneurial orientation scale: A multi-country analysis.

Entrepreneurship Theory and Practices, 26(4): 71-92.

Krugman, P. 1991. Increasing returns and economic geography, Journal of Political Economy, 99: 483-499.

Krgmnan, P. 1998. Space: the final frontier. Journal of Economic Perspectives, 12: 161174.

Lee, C., Lee, K., and Pennings, J.M. 2001. Internal capabilities, external networks and performance: A study on technology-based ventures. Strategic Management Journal, 22: 615-640.

Lengnick-Hall, C.A. 1992. Innovation and competitive advantage: what we know and what we need to learn. Journal of Management, 18(2): 399-429.

Lumpkin, G.T., and Dess, G.G. 1996. Clarifying the entrepreneurial orientation construct and linking it to performance. Academy of Management Review, 21(1): 135-172.

Lumpkin, G. T., and Dess, G.G. 2001. Linking two dimensions of entrepreneurial orientation to firm performance: The moderating role of environment and industry life cycle. Journal of Business Venturing 16(5): 429-451.

Lyon, D.W, Lumpkin, G.T. and Dess, G.G. 2000. Enhancing entrepreneurial orientation research: operationalizing and measure a key of strategic decision making process. Journal of Management, 26(5): 1055-1085.

McClelland, D.C. 1961. The achieving society. Van Nostrand, Princeton NJ.

McDougall, P.P, and Oviatt, B.M. 2000. International entrepreneurship: the intersection of two research paths. Academy of Management Journal, 43(5): 902-908. 
Miller, D. and Friesen, P.H. 1982. Innovation in conservative and entrepreneurial firms. Two models of strategic momentum. Strategic Management Journal, 3(1): 1-25

Miller, D. 1983. The correlates of entrepreneurship in three types of firms. Management Science, 29: 770-791.

Miller, D. 1990. Organizational configurations: cohesion, change, and prediction. Human Relations, 43(8): 771-789.

Nelson, R.R., and Winter, S.G. 1982. An evolutionary theory of economic change. Cambridge, MA: Belknap Press.

Penrose, E.T. 1959. The theory of the growth of the firm. Oxford: Basil Blackwell.

Penrose, E.T. 1995. The theory of the growth of the firm, third edition. Oxford: Oxford University Press.

Porter, M. E. 1980. Competitive Strategy: Techniques for analyzing industries and competitors. New York: The Free Press.

Sawyer, M.C. 1985. The economics of industries and firms, second edition, Croom Helm, London.

Siegfried, J.J. and Evans, L.B. 1994. Empirical studies of entry and exit: A survey of the evidence. Review of Industrial Organization, 9: 121-55.

Shadish, W.R., Cook, T.D., and Campbell, D.T. (2002). Experimental and quasiexperimental designs for generalized causal inference. Boston: Houghton Mifflin.

Shane, S. 1993. Cultural influences on national rates of innovation. Journal of Business Venturing, 8(1): 59-73.

Shane, S. 2000. Prior knowledge and the discovery of entrepreneurial opportunities. Organization Science, 11(4): 448-469.

Spector, P.E. 2006. Method variance in organizational research: Truth or urban legend. Organizational Research Methods, 2: 221-232.

Statistics Canada, Workplace and Employee Survey (WES) database, Statistics Canada, Ottawa, Ontario, Canada. Catalogue number 71-221-GIE.

Storey, D.J. 1985. The problem facing new firms. Journal of Management Studies, 22: 327-345.

Storey, D.J. 1994. Understanding the small business sector. Routledge, London/New York. 
Stuart, R.W., and Abetii, P.A. 1990. Impact of entrepreneurial and management experience on early performance. Journal of Business Venturing, 5(2): 151-162.

Tushman, M. and Andreson, P. 1986. Technological discontinuities and organizational environments. Administrative Science Quarterly, 31: 439-465.

Wicker, A.W., King, J.C. 1989. Employment, ownership and survival in micro business: a study of new retail and service establishments. Small Business Economics, 1: 137-152.

Wiklund, J. 1999. The sustainability of the entrepreneurial orientation-performance relationship. Entrepreneurship Theory and Practice, 24(1): 37-48.

Zahra, S. 1991. Predictors and Financial Outcomes of Corporate Entrepreneurship: An Explorative Study. Journal of Business Venturing, 6(4): 259-285.

Zahra, S. 1993b. Environment, corporate entrepreneurship, and financial performance: a taxonomic approach. Journal of Business Venturing, 8(4): 319-340.

Zahra, S. and Covin, J. 1995. Contextual influence on the corporate entrepreneurshipperformance relationship: a longitudinal analysis. Journal of Business Venturing, 10(1): 43-58. 